\title{
Gençlerin Bir Kentin Aidiyet Mekânı Olarak Inşasına Katılımı: Trabzon Hakkındaki Mitselleştirilmiş Anlatılar ve Trabzonspor Hatırası*
}

\author{
Gülmelek Doğanay' ${ }^{10}$
}

Öz Benlik bir mekânda var olmakla ilişkili ise, benliğe özgü anlatıların da bir mekânda vuku bulduğu bir gerçektir. Bu nedenle gençliği anlamak, özellikle gençliğin deneyimlediği mekânı analiz etmekle mümkün olacaktır. Bu çerçeveden hareketle, çalışma Trabzon'da yaşayan gençlerin kenti ne şekilde aidiyet mekânına dönüştürdüklerine odaklanmaktadır. Trabzon'da gençler kente olan aidiyetlerini çoğu zaman mitselleştirilmiş anlatılar, Trabzonspor taraftarlığına dayalı geçmiş hatıralar ve deneyimlenen mekânlar üzerinden inşa etmektedir. Trabzon kendisini deneyimleyen gençlere yoğun bir içeridelik hissi sağlamaktadır. Bu his onların kendilerini yuva olarak kabul ettikleri bu mekânda güvende hissetmelerine neden olmaktadır.

Bu çalışma yazarın doktora tezinden türetilmiştir ve onun saha verilerine dayanmaktadır. Çalışmada, toplumsal bir olgu olarak ele alınacak olan Trabzonlu gençlerin kente atfettikleri anlam sosyolojik bakış açısıyla açıklanmaya çalışılacaktır. Söz konusu amaç çerçevesinde anket, mülakat ve doküman inceleme gibi birden fazla bilimsel araştırma tekniği kullanılmıştır. Temelde nitel araştırma yöntemlerinin kullanıldığı yorumsamacı yaklaşım benimsenmiş ve derinlemesine mülakatlar ile görsel, işitsel ve yazılı dokümanların incelenmesi sonucunda elde edilen veriler, kapalı uçlu sorulardan oluşan anket uygulamasıyla da desteklenmiştir.

\section{Anahtar Kelimeler}

Gençlik, Gençlik araştırmaları, Mekân aidiyeti, Kent, Trabzon

\section{Participation of Youth in the Building of a City as a Place of Belonging: Mythicalized Narratives About Trabzon and Trabzonspor Memory}

\begin{abstract}
If self is related to being in a place, it is a fact that narratives special to the self, have also occurred in a place. Therefore, understanding youth will be possible by analyzing the place experienced by them. Within the framework of this approach, this study focuses on how young people living in Trabzon transform the city into a place of social belonging. In Trabzon, young people build a sense of belonging to the city mostly through mythicalized narratives, past memories and places they have experienced on the basis of being Trabzonspor supporters. Trabzon provides an intense feeling of inner belonging for young people who experience it. This feeling causes them to feel safe in this place, which they consider as home.

This study is derived from the author's doctoral thesis and is based on its field data. This study attempts to explain the meaning attributed to the city by Trabzonlu young people from a sociological perspective. For this purpose, multiple scientific research techniques such as questionnaires, interviews and documentation were used. Basically, the approach of hermeneutics which uses qualitative research methods has been adopted and the data, obtained through the examination of in-depth interviews and visual, audio and written documents' analysis, has been supported by a questionnaire consisting of closed-ended questions.
\end{abstract}

\section{Keywords}

Youth, Youth Studies, Belonging to Place, Urban, Trabzon

\footnotetext{
* Bu çalışma 2 Temmuz 2018 tarihinde Karadeniz Teknik Üniversitesi Sosyal Bilimler Enstitüsü’nde savunulan “Kentin Aidiyet ve Benlik Mekânı Olarak İnşası: Gençlerin Trabzon Deneyimi ve Trabzonluluk" başlıklı doktora tezinden türetilmiştir.

1 Sorumlu Yazar: Gülmelek Doğanay (Arş. Gör.), Karadeniz Teknik Üniversitesi, İktisadi ve İdari Bilimler Fakültesi, Kamu Yönetimi Bölümü, Trabzon, Türkiye. E-posta: melekalev@ktu.edu.tr ORCID: 0000-0001-9857-9310
}

Atıf: Doganay, G. (2019). Gençlerin bir kentin aidiyet mekânı olarak inşasına katılımı: Trabzon hakkındaki mitselleştirilmiş anlatilar ve Trabzonspor hatrası. SiYASAL: Journal of Political Sciences, 28(2), 207-235.

http://doi.org/10.26650/siyasal.2019.28.2.0021 


\section{Extended Summary}

The place is continuously constructed within the framework of the common meanings attributed by the actors who experience it and becomes an important element of belonging. This is also a process in which the self is built. If self is related to being in a place, it is a fact that narratives special to the self, have also occurred in a place. Therefore, understanding youth will be possible by analyzing the places experienced by them. Within the framework of this approach, this study focuses on how young people living in Trabzon transform the city into a place of social belonging. Trabzon provides an intense feeling of inner belonging for young people who experience it. This feeling causes them to feel safe in this place, which they consider as home. In Trabzon, young people build their sense of belonging to the city mostly through mythicalized narratives, past memories and places they have experienced on the basis of being Trabzonspor supporters.

The mythicalized narratives which are reproduced about Trabzon and being Trabzonspor supporters create a common sense of community among young people. It is assumed that the nationalist discourse is also being rebuilt while Trabzon and Trabzonluluk are exalted through mythicalized narratives. Each young person experiences the city through different places; however, there are also places where collective emotions appear and which are experienced in a collective way. The memories accumulated in these places that Trabzonspor supporters experience together strengthen the social belonging to the city and facilitate the integration of young people into the city. On the other hand, young people who participate in the reproduction of both mythicalized narratives and the places experienced collectively by being Trabzonspor supporters, contribute to the domination of the masculine values on the city. As a result, the city is defined by masculine characteristics.

This study is derived from the author's doctoral thesis and is based on its field data. This study attempts to explain the meaning attributed to the city by Trabzonlu young people from a sociological perspective. For this purpose, multiple scientific research techniques such as questionnaires, interviews and documentation were used. First of all, a questionnaire was prepared and completed after readings on the theory and literature research on youth and place belonging, and conversations with four young people from Trabzon. Afterwards, the necessary preparations for in-depth interviews were made through the information gathered from research into the literature and the results of the questionnaire. Interviews were then conducted. In the final stage, social media and photo and video sharing channels like Youtube that young people actively use were observed. As a result, both qualitative and quantitative data were obtained and analyzed. Basically, the approach of hermeneutics which uses qualitative research methods has been adopted and the data, obtained through the examination of in-depth interviews and visual, audio and written documents' analysis, has been supported by a questionnaire consisting of closed-ended questions.

According to the findings of the research, it is seen that young people living in Trabzon participate in the reproduction of mythicalized narratives about the city and can identify with Trabzon, which they spatialize through these narratives. Myths create an imaginary and fictional city image. The myths created about Trabzon state that the city is a safe 
place. The safety of the city emerges in the narratives produced through the heroism of the men living in the city. According to the narratives, the conquest of Istanbul was completed with the conquest of Trabzon and Trabzon is Turkey's last stronghold and the heart. This narrative, in whose reproduction young people also participate, is a narrative that can be heard by most of the people of Trabzon. This narrative shows that they are both national and urban nationalists. This also reinforces the belief that the city is the center of the region. Trabzon has lost its central position - being the economic, social and political center of the Black Sea Region- in the historical process, but the belief about city's central position is constantly being rebuilt by the narratives reproduced by the inhabitants of the city. This effort is similar to the crisis of power in which hegemonic masculinity enters. The fears of losing their power completely over the region pushes Trabzonlular to create an imaginary narrative for the preservation of the city image and to regain the position of being the 'big brother' of the region. Trabzonspor is one of the most important elements that enables this narrative to continue.

One of the elements that reinforces the urban nationalism and belonging to the city among the young people is being a Trabzonspor supporter. Football has always been an important sport for Trabzon in the historical process. Today, it is seen that Trabzonspor, which has an important place in the representation of Anatolia, shapes the daily life of the city. In Trabzon, which is decorated in the team's colours of claret red and blue before and after Trabzonspor matches, young people learn adulthood as a Trabzonspor supporter. Football can be effective in building identity at the local level, because it enables supporters to belong to a group. On the other hand, belonging to a group strengthens the attachment to the place where the group lives. The majority of young people living in Trabzon are Trabzonspor supporters and the Club covers a significant part of their daily lives. The youth whose daily life includes of claret red and blue, build a common feeling and memory around Trabzonspor. This memory appears in the narratives created about the years of the championships and of the trauma in which championships have been lost, as well as in the memory of places, such as Hüseyin Avni Aker. This collective memory reinforces the attachment of young people with the city. 


\section{Gençlerin Bir Kentin Aidiyet Mekânı Olarak İnşasına Katılımı: Trabzon Hakkındaki Mitselleștirilmiş Anlatılar ve Trabzonspor Hatırası}

Mekân, onu deneyimleyen aktörlerin ona yüklediği ortak anlamlar çerçevesinde sürekli inşa edilmekte ve aidiyetin önemli bir unsuru haline gelmektedir. Bir kente olan aidiyet o kente dair mekânlarda geçen gündelik pratiklerin gözlemlenmesi ile açıklanabilmektedir. Bir birey kendi hayat hikâyesini, yani varlığını ya da kimliğini inşa ederken bu deneyimlediği mekânlara hâkim olan pratiklerden beslenmektedir. Aslında kimlik ve mekân bilincinin oluşması işte tam da bu gündelik hayata dair anlatıların oluşturulmasına dayanmaktadır (Schick, 2000: 25). Kendilik anlatıları bir mekâna, hatta kültürel bir mekâna aittir, başka bir ifadeyle bir mekânda geçmektedir (Christou, 2006: 32). Bu çalışmada Trabzonlu gençlerin anlatılarında vücut bulan bir mekâna, Trabzon'a değinilecektir. Trabzon'da gençler kente olan aidiyetlerini çoğu zaman mitselleştirilmiş anlatılar, geçmiş hatıralar ve deneyimlenen mekânlar üzerinden inşa etmektedir. Söz konusu inşanın hiçbir zaman tamamlanmayan bir süreç olduğu da göz ardı edilmemelidir. Kendisini de inşa ettiği bu süreçte gençler, bir yeri söylemsel araçlar ve stratejilerle birlikte "anlamlandırmakta, insanileştirmekte, toplumsallaştırmakta yani mekânsallaştırmaktadır" (Schick, 2000: v). Mekânsallaştırma bir yerin insanlarla birlikte paylaşılarak anlamlandırılması ile gerçekleşmektedir (Tuan, 2001: 138). Dolayısıyla de Certeau (2008)'nun da ifade ettiği gibi gücü elinde bulunduran iktidarın stratejilerinin yanında, birey de geliştirdiği taktiklerle mekânın inşasında aktif role sahiptir. Kenti ya da mekânı deneyimleyen kullanıcılar birlikte bir öykü yazmaktadır.

Çalışmanın amacı, Trabzonlu gençlerin Trabzon'un bir mekân olarak üretimine nasıl katıldığı ile yer duygusunu bu mekân üzerinden nasıl inşa ettiğini anlamaya çalışmaktır. Kendiledikleri ve kök saldıkları Trabzon'u ona atfettikleri bireysel ve kolektif anlamlar çerçevesinde bir mekân olarak inşa eden Trabzonlu gençler, kenti güvenli bir sı̆̆ınak ve yuva olarak kurgulamaktadır. Bu çerçeveden hareketle, gençlerin, mitselleştirilmiş anlatılar ve futbol takımı taraftarlığı aracılığıyla bireysel ve kolektif aidiyet unsuru haline gelebilen mekânın yeniden üretimine nasıl katıldığı sorunsallaştırılmaktadır. Trabzon'a dair yeniden üretilen mitselleştirilmiş anlatılar ve Trabzonspor taraftarlı̆̆ gençlerde ortak bir cemaat duygusunun oluşmasını sağlamaktadır. Mitselleştirilmiş anlatılar yoluyla Trabzon ve Trabzonluluk yüceltilirken, milliyetçi söylemin de yeniden inşa edildiği varsayılmaktadır. Her bir genç kenti farklı mekânlar üzerinden deneyimlemektedir; ancak ortak duygunun oluşmasını sağlayan ve kolektif bir şekilde deneyimlenen mekânlar da bulunmaktadır. Trabzonsporlu taraftarların birlikte deneyimledikleri söz konusu mekânlarda biriktirilen hatıralar da kente olan aidiyeti kuvvetlendirmekte ve gençlerin kentle bütünleşmesini kolaylaştırmaktadır. Hem mitselleştirilmiş anlatıların hem de Trabzonspor taraftarı olmak ile kolektif bir şekilde deneyimlenen mekânların yeniden üretimine katılan gençler, diğer taraftan eril değerlerin de kente hâkim olmasına katkı sağlamaktadır. Bu durum, kentin eril özellikler üzerinden tanımlanması ile sonuçlanmaktadır. Çalışmanın sorunsalı çerçevesinde araştırmanın bulgular kısmında Trabzon'un bir "yuva” olarak nasıl kurgulandığından, ayrılış ve dönüş anlatılarının “dışarısı"nı nasıl inşa ettiğinden, kentin mitselleştirilmesinden, Trabzonspor'un ve Trabzonsporluluğun mekânın inşasına katkısından bahsedilecektir. 
Bu çalışmada, toplumsal bir olgu olarak ele alınacak olan Trabzonlu gençlerin kente atfettikleri anlam sosyolojik bakış açısıyla açıklanmaya çalışılacaktır. Söz konusu amaç çerçevesinde anket, mülakat ve doküman inceleme gibi birden fazla bilimsel araştırma tekniği kullanılmıştır. Öncelikle gençlik ve mekân aidiyeti konusunda teori ve literatüre ilişkin yapılan okumalar ile dört Trabzonlu gençle gerçekleştirilen sohbetin ardından anket soruları hazırlanmış ve uygulanmıştır. Daha sonra derinlemesine mülakatlar için gerekli olan hazırlıklar anket uygulanarak deneyimlenen araştırma sahasının verdiği ipuçları doğrultusunda yapılmış ve görüşmeler gerçekleştirilmiştir. Son aşamada ise, gençlerin aktif bir şekilde kullandıkları sosyal medya ve Youtube gibi fotoğraf ve video paylaşım kanalları gözlemlenmiştir. Sonuç olarak hem nitel hem de nicel veriler elde edilerek analize tabi tutulmuştur. Temelde nitel araştırma yöntemlerinin kullanıldığ 1 yorumsamacı yaklaşım benimsenmiş ve derinlemesine mülakatlar ile görsel, işitsel ve yazılı dokümanların incelenmesi sonucunda elde edilen veriler, kapalı uçlu sorulardan oluşan anket uygulamasıyla da desteklenmiştir.

Çalışma üç ana bölümden oluşmaktadır. İlk bölümde araştırmanın kavramsal çerçevesinden bahsedilecek, mekânın yeniden üretimi ve aidiyet ile olan ilişkisi tartışılacak ve kısaca ilgili literatüre yer verilecektir. İkinci bölümde araştırmada kullanılan metodoloji, kullanılan teknikler ve benimsenen yaklaşım çerçevesinde aktarılacaktır. Son bölümde ise araştırmanın sahasından elde edilen bulgular sorunsal ile ilişkili olarak değerlendirilecektir.

\section{Araştırmanın Kavramsal Çerçevesi}

Cresswell (2008: 15) mekânı sadece gözlemlenebilir, araştırılabilir ve yazılabilir bir araştırma nesnesi olmaktan ziyade; görmek, araştırmak ve yazmak için bir yöntem olarak kabul etmektedir. Bu çalışmada da Trabzon kenti bir mekân olarak ele alınmış, söz konusu mekân Trabzonlu gençlerin kente aidiyet inşalarını anlamak, araştırmak için bir yöntem olarak seçilmiştir. Literatüre coğrafyacılar tarafından kazandırılan "mekân” kavramını ele alan çeşitli yaklaşımlar bulunmaktadır. Bunların ilki fenomenolojik yaklaşımdır. Kültürel çalışmalar çerçevesinde mekânı anlamaya çalışanlar da vardır. Mekânın hem toplumsal ilişkiler hem de özne-aktör tarafindan inşa edildiğini; benzer şekilde toplumsal ilişkiler ile özne-aktörün kimliği ve gündelik hayatının mekân tarafından şekillendirildiğini kabul edenler de bulunmaktadır. Bu bölümde, çalışmanın sorunsalı kapsamında sadece mekânın yeniden üretimi ve aidiyet unsuru haline gelişine dair kavramsal çerçeveden bahsedilecek ve gençlik ile mekân arasındaki ilişkiyi ele alan az sayıdaki ulusal literatüre değinilecektir.

Mekân sadece içine nesneler doldurulmuş bir boşluk, hissedilir olgular toplamı, fiziksel bir gerçekliği olan şekil değil, aynı zamanda içinde insan ilişkilerini barındıran anlamlarla yüklü canlı bir varlıktır (Lefebvre, 2014: 46, 57; Schick, 2000: 5). Mekânın örgütlenmesi ve anlamı toplumsal dönüşümün, aktarımın ve deneyimin bir ürünüdür (Soja, 1989: 79-80). İnsanlar mekânı deneyimler ve ortak anlamlar üretirler, böylece mekânı toplumsal olarak; binalar, yollar, parklar vs. inşa ederek de maddi olarak yaratırlar (Cresswell, 2008: 30). Lefebvre (2014: 24)'ye göre mekân ve mekânsallık, ekonomik ve toplumsal ilişkilerin hem ürünü hem üreticisidir. Üretim tarzı kendi mekânını oluşturur, hiyerarşikleşmiş toplumsal faaliyetleri birbirinden ayırır (iş bölümü). Söz konusu hiyerarşik ilişkiye dayalı üretim 
ilişkilerinin temsilleri mekânda anıt, bina, sanat eseri olarak cisimleşir (Lefebvre, 2014: 6162). Edward Soja'ya göre küreselden yerele hayatın bütün evrelerinde toplumun mekânsal organizasyonu krizdeki kapitalizmin acil ihtiyaçlarına göre yeniden yapılandırılmıştır; toplumsal kontrolü sağlamanın yeni yollarını bulmak için, üretim ve tüketim artışını yönetebilmek için bu mekânsal organizasyondan faydalanmaktadır. Yani üretim ilişkilerine göre şekillenen mekân toplumsal olarak üretilmektedir (Soja, 1989: 25, 34, 121). David Harvey de mekânın (ve zamanın) nesnel anlamının toplumsal yeniden üretim ilişkileri tarafından yaratıldığını düşünmektedir. Harvey, planlamacıların yaratmış olduğu mekâna göre gündelik pratiklerin şekillendiğini kabul etmektedir. Ancak buna rağmen gündelik pratikler iktidarın dayattığı sabit temsillerden kaçabilme gücü de sunmaktadır (Harvey, 2012: 227-231). Doreen Massey (2001: 117)'e göre de mekân, uluslararası sermaye birikim süreçlerinin ürünleridir. Buna rağmen yerel coğrafi özellikler de barındırmaktadır. İnsanları mekâna bağlayan anlamlar ve semboller yani coğrafi öznellikler göz ardı edilmemelidir. Bir coğrafyacı olarak mekânın postmodern tanımını yapmaya çalışan Massey, insan unsurunu da göz önünde bulundurmakta, mekânı salt geometrik bir nesne olarak ele almamaktadır. Ona göre mekân (sosyal mekân olarak tanımlıyor), toplumsal ilişkilerin diğerleriyle etkileşim esnasında zorunlu olarak aldığg mekânsal bir formdur. Bu anlamıyla mekân inşa edilen, belirlenen, diğerleriyle etkileşime girilen, bozulan ve yeniden kurulan toplumsal ilişkilerin gerçekleştiği yerdir (Massey, 2001: 118-120).

Toplumsal ilişkilerin gerçekleştiği ve sürekli yeniden inşa ettiği yer olan mekân aynı zamanda bireyler için aidiyet unsuru haline gelebilmektedir. Literatürde insanların mekânla kurdukları bağı ifade eden farklı kavramlar ve söz konusu bağın oluşmasında etkili olan unsurların varlığına ilişkin çalışmalar bulunmaktadır. Bu anlamda “yere bağlılık” önemli kavramlardan biri olarak kabul edilmektedir. Söz konusu kavram, bireyin fiziksel bir mekâna olan duygusal bağını ve etkileşim sonrasında mekâna yüklediği anlamı ifade etmek için kullanılmaktadır (Milligan, 1998: 2-7).

Fenomenologlar mekâna olan aidiyeti varoluş çerçevesinde ele almaktadırlar. Heidegger (2004: 95)'e göre, insanın yaşadığ çevreye duyduğu aidiyet bir yerin içinde olma durumundaki Varlıkla ilişkilidir. Varlık, içinde bulunduğu yerdeki diğer varolan şeyleri yakından tanır, onları bilir ve böylece dünyaya aitlik hisseder. Aidiyet duygusu kişi ve mekân arasındaki duygusal bağı işaret etmektedir (Seamon, 1979: 75). Relph (1976: 11)'e göre de insanın kendisini güvende hissettiği, düzenli ve durağan, anlamlarla dolu, kendilik inşasının gerçekleştirildiği ve hatıraların biriktirildiği özel mekânlar, anlamlar ve niyetlerle dolu algısal yerlerdir. Anlamın ortaya çıkması insan deneyimine bağlıdır. Mekânın fiziksel unsurlarını deneyimleyen bireyler birlikte oraya ait bir anlam üretirler. Relph insanların deneyimleri ile ortaya çıkan tüm bu anlamları "mekânın ruhu", "yer duygusu" ya da "genius loci" denen ve karakter ya da kişiliğe tekabül eden kavramlarla açıklamaktadır (Relph, 1976: 47-48).

Yer duygusu, çevreye olan duygusal bağı ifade etmektedir. Gündelik hayatın kişisel ve toplumsal deneyiminde ortaya çıkmaktadır. Mekâna doğru olan kişisel yönelimdir. Yani bir kişinin mekânı algılama ve ona karşı duyduğu his biçimidir (Hummon, 1992: 262). Bu Tuan'ın "yer sevgisi” olarak tanımladığı şeydir. Yer/uzam ve mekân arasındaki farkın ortaya konulması gerektiğini savunan Tuan (2001: 3)'a göre mekânı yer/uzamdan farklı kılan şey ona duyulan aidiyettir. Mekân aynı zamanda güvende olma hissi sunmaktadır 
(Christou, 2006: 33). Yer ise mekâna göre oldukça soyut bir kavramdır ve hareketi içerirken, mekân ise bu hareketlilik içerisinde bir hareketsiz noktaya (dinlenme/duraklama) işaret eder. Söz konusu duraklama, yer duygusunun oluşmasına olanak sağlamaktadır (Tuan, 2001: 138). Hummon (1992: 262-263), yer duygusunun “cemaat duygusu” ile oluştuğunu savunmaktadır. Cemaat duygusunun üç farklı biçimi olan tatmin, aidiyet ve kimlik aynı zamanda yer duygusunun da farklılaşmasına neden olmaktadır. İnsanlar üyeleri oldukları cemaate özgü bakış açılarına bağlı olarak, kök salma, yabancılaşma ve yersizlik gibi farklı yer duygularına sahiptirler. Mekânların hem kolektif hem de bireysel deneyimi bağlılık, benzerlik ve yakınlık duygularını beraberinde getirir. Bu, özel mekânda diğerlerini tanımayı ve diğerleri tarafından tanınır olmayı deneyimlemek demektir. Söz konusu bağlılık mekâna kök salmamızı sağlamaktadır (Relph, 1976: 37). Kök salma sayesinde insanların gündelik rutinleri otomatik olarak gerçekleşmektedir, çünkü çevre artık bilinir bir çevre olmuştur. Kök salma ne kadar fazla zaman geçirilirse o kadar çok güçlüdür (Seamon, 1979: 79-80). Kök salma duygusu insanların yaşadıkları çevreye olan bağını kuvvetlendirmektedir.

Her birey mekânlara, nesnelere ve alanlara güçlü aidiyet duygusu deneyimler: "Aile evi”, "benim favori koltuğum", "eski mahalle", "New York ve Londra benim kentlerim", "benim en sevdiğim odam" gibi cümleler kurarar (Proshansky, 1978: 157-158). Bu tanımlama bizi “kendileme” kavramına götürmektedir. Kendileme kavramı 1960'lardan bu yana kent sosyologları ve çevre psikologları tarafından mekânın kendilenmesi bağlamında kullanılmaktadır (Göregenli, 2010: 123). Kendileme, bir mekânı kendinin kılmak, onu kontrol etme, anlamlandırma, kullanım yetkisine sahip olmaktır. İnsanlar bir nesne ya da yere karşı psikolojik, toplumsal ve kültürel bir bağ kuruyorsa onu kendisinin k1liyor demektir (Werner vd., 1985: 5). Mekânı kendileme onun üzerinde otorite kurma, denetim ve güç sahibi olmak anlamına gelmektedir (Bilgin, 2013: 133). Ancak mekânın kamusal anlamları da vardır. Bir şehrin güzel olduğunu belirtmek ortak bir duyuyu ifade etmesi anlamında kamusaldır (Cresswell, 2008: 1). Bu anlamda kendileme sahiplenmekten farklıdır. Kente, mahalleye, sokaklara sahip olmak mümkün değildir, ancak bu mekânlara kendimizden bir şeyler katmamız mümkündür (Göregenli, 2010: 124). Bir bina, yap1 ya da anıta sahip olabiliriz, ama bir sit alanı, meydan ve sokağın mülkiyetine sahip olamasak da onları kendimizin kılabiliriz. Çünkü bu mekânlar, orada oturanların yaşantılarını yansıtır, onların öykülerini anlatırlar (Lefebvre, 2014: 183-184).

Görüldüğü üzere yere bağlılık, yer duygusu, cemaat duygusu, kök salma ve kendileme kavramları, aidiyet ve kimliğin nasıl oluştuğunu ifade etme noktasında benzer tanımlamalara sahiplerdir. Birbirini tamamlayan hatta birbirlerinin yerlerine kullanabilecek kadar benzeyen söz konusu kavramlar insan ile mekân arasındaki ilişkinin analizinde önemli araçlar olarak belirmektedir. Kentin bizatihi kendisinin de bir aidiyet unsuru olarak belirdiği görülmektedir. Trabzon'da gençler Trabzon kentine ilişkin ortak anlamlar üretmekte ve onu diğer kentlerden ayırmaktadırlar. Trabzon onlar için bir yuvadır. Gençler, Trabzon'a ilişkin hikâyeler ve mitler oluşturarak kenti kendilik inşalarına katmaktadırlar. Bu, hem Trabzon'u hem de Trabzonluluğu inşa ettikleri bir süreçtir.

Gençlerin bir mekâna olan aidiyetlerini ölçen çalışmalar literatürde oldukça azdır. İsmail Doğan (1994)'ın Bir Alt Kültür Olarak Ankara Yüksel Caddesi Gençliği çalışması gençlerin toplumsal normlar ve ilişkilerden farklı bir alt kültürü nasıl inşa ettiğini onların 
Ankara Yüksel Caddesi deneyiminden yola çıkarak ortaya koymaktadır. Zamanlarını söz konusu caddede geçiren bu gençler yaşam ve giyim tarzları ile farklı bir kültürel grup oluşturmaktadırlar. Deniz Yonucu (2005)'nun From the Place of the “Dangerous Classes" to the Place of Danger: Emergence of New Youth Subjectivities in Zeytinburnu başlıklı yüksek lisans tezi de tehlikeli olarak imlenen Zeytinburnu semtinin gençlere nasıl bir öznellik mekânı sunduğunu açıklamaktadır. Bu çalışmada yazar, Zeytinburnu'nda yaşayan gençlerin neoliberal tüketim toplumuna eklemlenme çabalarının orta sınıf taklitçiği, suçluluk, uyuşturucu satıcılığı ve clubberlık şeklindeki öznellikler inşa etmeleri ile sonuçlandığını belirtmektedir. Hakan Yücel (2006) Une identité générationnelleterritorial? Les jeunes d'origine alévie du quartier Gazi d'Istanbul başl1kl1 doktora tezinde kendisini toplumsal olarak damgalanmış Gazi Mahallesi üzerinden tanımlayan Alevi gençlerin kentsel hareketin yeni toplumsal aktörleri olarak nasıl ortaya çıktığını ortaya koymaktadır. Söz konusu çalışmada Alevi, genç ve damgalanmış bir mahalle sakini olan bu yeni aktörlerin ayaklanmaları analiz edilmektedir. Çalışma mekânsallığın kimlik inşasındaki etkisini kabul etmektedir. A. Çağlar Deniz (2014) "Öğrenci $\dot{I}_{s ̧ i}$ ” Üniversite Ögrrencilerinin Gündelik Hayatı: İstanbul Örneği başlıklı çalışmasında taşradan metropole gelen gençlerin kent yaşamına uyum sağlama taktiklerini analiz ederken, gençlerin mekânla olan ilişkisine değinmiştir. Çalışma daha çok gençlerin aidiyetini oluşturan bir çok unsurun (din, etnisite, cinsiyet, kültür gibi) metropol kent mekânlarındaki pratiklerini nasıl etkilediğiyle ilgilenmektedir.

Sonuç olarak gençlik ve mekân teorisinin kesiştiği çalışmalar oldukça azdır. Bu anlamda Trabzonlu gençlerin mekân aidiyetinin analiz edildiği bu çalışma litaratüre bir katkı sunmayı amaçlamaktadır. Çalışmada hem nitel hem de nicel araştırma teknikleri bir arada kullanılmıştır. Bir sonraki bölüm araştırmanın metodolojisine ayrılmıştır.

\section{Araştırmanın Metodolojisi}

Araştırmanın sahasını Trabzon kent merkezi oluşturmaktadır. Dışarıdan bakıldığında Trabzon, onu deneyimleyenleri açısından kuvvetli bir aidiyet mekânı özelliği sergilemektedir. İçine girildiğinde ise, Trabzonlulara has bir mikromilliyetçiliğin varlığ daha açık bir şekilde görülebilmektedir. Bu nedenle araştırma sahası olarak Trabzon seçilmiştir. Trabzon'un araştırma sahası olarak seçilmesinin bir diğer nedeni ise, elbette sosyal bilimler alanında çalışan bir araştırmacının (özellikle sosyoloji ile ilgileniyorsa) etrafında olup bitenlere daha duyarlı olmasından kaynaklanmaktadır. Hele dışarıdan gelen ama yedi yıl gibi uzun bir süre kenti deneyimleyen araştırmacı için bir araştırma sahası olarak beliren Trabzon, aynı zamanda onun araştırma nesnesine de dönüşmektedir.

$\mathrm{Bu}$ çalışmada kullanılan veriler yazarın doktora tezi için yaptığı saha araştırmasına dayanmaktadır. Söz konusu araştırma için etnometodoloji bilimsel bir yaklaşım olarak tercih edilmiştir. Etnometodoloji gündelik hayat pratiklerinin analizini gerektirdiğinden, gençlerin Trabzon kentini nasıl mekânsallaştırdıklarının anlaşılmasında yardımcı olmaktadır. Etnometodoloji, gündelik hayatın içinde aktörlerin birbirleriyle kurdukları ilişkileri hangi metot ve prosedürlerle gerçekleştirdiklerini analiz etmektedir. Bu metotlar ve prosedürler (etnometotlar) bir toplumun ya da toplumsal grubun üyeleri tarafindan paylaşılmaktadır (Coulon, 2015: 10). Gerçekte etnometodoloji insanların toplumsal bir olguya yükledikleri anlamları açıklamaya çalışmaktadır. 
Gündelik hayat deneyimleri ve pratiklerinin bilimsel analizyöntemi olan etnometodoloji, aktörler tarafından kavranan (refleksivite) gündelik hayat dilinin, hareketlerinin, eylemlerinin, kurallarının her birinin etkileşim esnasında yeniden üretildiğini dolayısıyla bağlama-gönderimli olduğunu kabul etmektedir. Bununla birlikte bir topluluğun üyesi olduğu müddetçe aktör, uyum sağladığı çevreye dair anlamlar üretebilmekte ve eyleminin anlamı başkaları tarafından anlaşılır ise (açıklanabilir ise) ortak toplumsal dünya oluşabilmektedir (Coulon, 2002: 23-43). Toplumu oluşturan üyelerin gündelik hayat pratiklerini yerine getirirken kullandıkları metotlar aktörlerin gündelik etkinliklerini 'görünebilir, rasyonel ve rapor edilebilir', başka bir ifadeyle 'açıklanabilir kılmakta'dır. Bu nedenle de söz konusu metotların incelenmesi gerekmektedir (Garfinkel, 2014: 7). Bu çalışma kapsamında da katılımcıların Trabzon kentine ait ürettikleri ve yeniden ürettikleri anlam, gündelik hayat deneyimleri ve kullandıkları metotlar ile bağlama-gönderimli söylemleri üzerinden yola çıkılarak anlaşılır kılınmaya çalışılmıştır. $\mathrm{Bu}$ anlamıyla Trabzon'da yaşayan gençlerin anlatıları ile sosyal medyada paylaştıkları fotoğraflar ve videoların analizleri çalışma için oldukça önemlidir.

$\mathrm{Bu}$ çalışmada hem nitel hem de nicel veri toplama tekniklerinden faydalanılmıştır. Bu kapsamda derinlemesine mülakat, anket ve doküman inceleme (sosyal medya paylaşımları, fotoğraflar, videolar vb.) teknikleriyle saha araştırması gerçekleştirilmiştir. 2016 yılının Haziran-Eylül ayları arasında anket formu ve yarı yapılandırılmış mülakat formu hazırlanmıştır. Nitel ve nicel araştırma yöntemlerini kullanarak, ampirik bulgular elde etmeyi amaçlayan çalışma kapsamında, kartopu yöntemiyle 15-28 yaş arasındaki 38 genç ile Trabzon’da 2017 yılının Şubat-Mayıs ayları arasında derinlemesine mülakatlar gerçekleştirilmiştir. Katılımcılar kendi deneyimlerinden bahsederlerken, üzerlerinde öznel bir etki bırakılmamaya özen gösterilmiştir. Bu nedenle de yarı yapılandırılmış görüşme tekniği ile sorular sorulmuştur. Net, kesin, direkt, yönlendirici sorular yerine konu başlıklarının yer aldığı bir görüşme kılavuzu hazırlanmıştır (Giraud, 2010: 46-47). Yarı yapılandırılmış mülakat formu pilot çalışma ile katılımcıların öne çıkardıkları konular üzerinden her defasında güncellenmiş ve son halini almıştır. Bu araştırmada katılımcıların siyasi, kültürel, ekonomik, yaş, cinsiyet vb. kriterlere göre olan farklılıkları dikkate alınarak (daha önceden yapılan telefon görüşmesi ya da sosyal medya hesaplarının incelenmesi ile elde edilen bilgilerle) mülakatlar sorunsuz bir şekilde gerçekleştirilmiştir.

Öte yandan, tüm görüşmelerin, katılımcıların da izniyle, ses kayıt cihazı ile kayıt altına alınabilmesi ve raporlanabilmesi sağlanmıştır. Yapılan derinlemesine mülakatlar ortalama her bir katılımcıyla 56 dakika sürmüş ve toplamda yaklaşık 2145 dakikalık ses kaydı elde edilmiştir. Söz konusu ses kayıtları katılımcıların ifadeleri hiç değiştirilmeden deşifre edilerek (çözümlenerek) yazıya dökülmüş ve toplamda 540 sayfalık yazılı dokümana ulaşılmıştır. Söz konusu metin defalarca okunmuştur. Ardından katılımcıların söylemleri temalara ayrılmış ve her bir tema kodlanmıştır. Söz konusu temalar çerçevesinde her bir katılımcının öznel anlam dünyaları analiz edilmiştir. Buradan yola çıkılarak ortak anlam dünyaları keşfedilmeye çalışılmış ve veriler kuramsallaştırılmıştır.

Derinlemesine mülakatların yanında yazılı, işitsel ve görsel dokümanların incelenmesiyle de araştırmanın sorunsalına ilişkin daha kapsamlı veriler elde edilebilmiştir. Trabzon'un gençlerin aidiyet ve varoluş ihtiyacını nasıl karşıladığı anket 
ve mülakat dışında gençlerin sosyal medyadaki yazılı ve görsel paylaşımları dolayısıyla da analiz edilmeye çalışılmıştır. Bu kapsamda Youtube kanalında paylaşılan klipler ve kısa skeçlerden oluşan videolar, söz konusu videoların altında yapılan yorumlar, taraftar gruplarının sosyal medya kanalları üzerinden yapmış oldukları yorumlar ve fotoğraf paylaşımlarının bir dökümü yapılmıştır. Yaklaşık dört aylık bir çalışma ile gençlerin Trabzonluluğa ilişkin paylaştıkları görsel ve yazılı materyaller toplanmıştır. Söz konusu dokümanlar analiz edilmiş ve yorumlanmıştır.

Çalışma kapsamında nicel araştırma yöntemlerinden olan anket tekniği de uygulanmıştır. Anket, derinlemesine mülakatlarda olduğu gibi Trabzon' da yaşayan 15-24 yaş arasındaki farklı gruptan 395 gence uygulanmıştır. Evrensel anlamda gençliğin 15-24 yaş arasındaki kişilerden oluştuğu kabul edilmektedir. Bu nedenle 15-24 yaş arasındaki gençlere anket uygulanmasına karar verilmiştir. Ancak derinlemesine mülakatlar ise, 15-28 yaş arasındaki gençlerle gerçekleştirilmiştir. 24 yaşından daha büyük olmasına rağmen toplumsal anlamda gençlik kategorisinde yer aldığı fark edilen birkaç gençle de görüşmeler yapılmıştır. Bu durum ailesiyle yaşayan, ekonomik anlamda aileden bağımsız hareket edemeyen ve düzenli bir yetişkin hayatına sahip olmayan katılımcıların uzayan gençlik kategorisinde değerlendirilmesinden kaynaklanmaktadır. 2016 yılının Ekim ayında uygulanmaya başlanan anketler, 2017 yılının Şubat ayında tamamlanmıştır. Anketler üniversitede, etüt merkezlerinde, liselere yakın kafelerde, kuaför ve diğer esnaf dükkânlarında ve sokakta yüz yüze gerçekleştirilmişstir.

Anket için derinlemesine mülakattan daha büyük bir örneklem belirlenmiştir. TÜİK (2013: 84, 100) verilerine göre, Trabzon ilinde 15-24 yaş arasında 126.326; Ortahisar ilçesinde ise 52.543 genç yaşamaktadır. 2016 verilerine göre ise, Trabzon ilinde 15-24 yaş arasındaki genç nüfusunun toplamda 118.910 olduğu görülmektedir (TÜİK, 2016). TÜİK'in internet sitesinden Ortahisar ilçesine (İl merkezi ve çevresi) ait 15-24 yaş arasındaki güncel genç nüfus verilerine ulaşılamamıştır. TÜİK Trabzon şubesinden 2016 Ortahisar ilçesine ait genç nüfusu mail aracılığıyla talep edilmiştir ve 2016'da Trabzon'un Ortahisar ilçesinin 15-24 yaş arasındaki genç nüfusunun 55.597 olduğu öğrenilmiştir. Önce 2013 verilerine göre hesaplanan örneklem büyüklüğü 2017'ye girildikten sonra güncel verilerle tekrar hesaplanmıştır. Sonuç olarak, \%95 ( $\alpha=0.05)$ güvenilirlik aralığında $\pm \% 5$ örnekleme hatası ile örneklem büyüklüğü 382 olarak belirlenmiştir. Bu araştırmada anket uygulanan katılımcılar tesadüfi örnekleme yöntemi ile belirlenmiştir. Lise ve üniversite öğrencileri ile birlikte, ilkokul ve lise mezunu veya eğitimine devam etmeyen, çalışan veya işsiz 15-24 yaş arasındaki erkek ve kadın gençlere toplamda 395 anket uygulanmıştır. Çalışma kapsamında uygulanan anket verileri SPSS programına girildikten sonra betimsel istatistiklerden faydalanılmıştır. Her bir anket sorusu için cevapların yüzdesinin görünür olduğu frekans tabloları ile çapraz tablolar hazırlanmış ve yorumlanmıştır. Bununla birlikte bazı ölçeklere Faktör analizi de uygulanmıştır.

Tüm bu tekniklerle elde edilen verilere göre, gençlerin Trabzon'a olan aidiyeti mekâna duyulan bağ ile mekâna yüklenen anlam çerçevesinde şekillenmektedir. Trabzonspor taraftarlığ 1 ise, söz konusu aidiyetin önemli bir tamamlayıcı unsurudur. Araştırma bulguları gençlerin kendilerini Trabzon'a ait hissetmelerinin çok farklı nedenleri (ekonomik, kültürel, siyasal, coğrafi vs.) olduğunu ortaya koymaktadır. Ancak bu çalışmada sadece 
birkaçına değinilecektir. Aşağıdaki bölümlerde ortak anlamlarla mekânsallaştırılan kentin gençler nezdinde bir yuva olarak tanımlanmasından ve bu yuvaya hissedilen ortak duygunun mitselleştirilmiş anlatılar ve Trabzonspor taraftarlığı aracılığıyla nasıl pekiştiğinden bahsedilecektir.

\section{Araştırmanın Bulguları}

\section{Kendini 'Yuva'da Hissetmek}

Trabzon'da yaşayan gençler tüm farkl1lıklarına rağmen bu kente ilişkin ortak anlamlar üretmektedir. Trabzon'u kendilerine ait kılan gençler mekânı, mekân da onların kimliklerini, toplumsallıklarını inşa etmektedir. Söz konusu durum kişinin varlığının farkına varması ile de ilişkilidir. Çünkü mekân ile varlık arasında sıkı bir ilişki bulunmaktadır. İnsan varlığı toplumsal olana bağlı olduğu kadar mekâna da bağlıdır, çünkü toplumsal ilişkilerin gerçekleşmesi bir mekâna ihtiyaç duymaktadır. Bu anlamda mekâna yüklenen anlam oldukça önem arz etmektedir, çünkü mekân insanın ona anlam kattığı yerdir (Pickles, 1985: 158). Mekân içinde olunandır, yani yaşanılan, alışılan, tanınan bir yerdir. Bu içeridelik hali de varoluşla alakalıdır (Heidegger, 2004: 90). Kişinin bir mekâna kendisini ait hissetmesi, ona bağlanması, kök salması ve kendisine dünyada güvenli bir nokta bulması insani bir ihtiyaçtır (Relph, 1976: 38). Özellikle yaşanılan bu zamanda teknolojinin gelişimine bağlı olarak hareketliliğin artması zaman ve mekân sıkışmasına neden olmakta, zamanın ve mekânın sınırlarının aşılmasını sağlamaktadır. $\mathrm{Bu}$ durumun yarattığı güvensizlik hissinden ötürü insanlar bir şeye ya da bir mekâna bağlanma ihtiyacı duymaktadır (Massey, 2001: 151).

Trabzon'un kendilerine ait bir mekân olduğunu bilmek, çoğu genç katılımcının içini rahatlatan ve kendisini güvende hissetmesini sağlayan bir duygudur. Bacherlard (2013: 27-28) söz konusu duyguyu, mekânın mutlu olunan, sahiplenilen, başkalarına karşı savunulan, övülen yani sevilen bir yer olması anlamında, "yer sevgisi” (topophilia) kavramı ile açıklamaktadır.

Beni Trabzon'a bağlayan şey kader, burada doğdum bir kere. Eskiden şöyle bir şey şöyle bir tweet atmıştım: Hani Allah'ım sana çok şükür Türkiye'de doğmuşum. Müslüman bir ülke kökeni olan bir ülke. Türk’üz yani. Türk olmak benim için hep gurur olmuştur. Yani ne mutlu Türküm sözünü içten söyleyenlerden biriyim. Ve hep şey derdim, böyle iyi ki de Trabzon'da doğmuşum derdim. En azından hani bir buraya dışardan gelmek var, bir de buradan dışarıya gitmek var. Buradan dışarıya gitmek daha iyi. En azından burası sana ait bunu bilirsin (K2, kadın, 21 yaş, üniversite öğrencisi).

Bence Trabzon herkesin yaşaması gereken bir yer. Mutlaka yani ben Trabzonsuz bir hayat düşünemiyorum hani. Türkiye'nin neresi olursa olsun bu kadar özgüvenli bir şehir zaten yok. Herkesin mi bir özgüveni olur, herkeste görüyorum ben onu. Ben Trabzonluyum deyince çok farklı oluyor, sanki dünyanın merkezinde yaşıyormuşsun gibi (K3, kadın, 20 yaş, üniversite öğrencisi).

Dünya'nın neresinde yaşanırsa yaşansın Trabzon'un varlığını bilmek bile katılımcılara göre yeterlidir. Söz konusu duygunun bir dişa vurumu olarak da sloganlaşan 'Bize her yer Trabzon’ metaforu sınırları belli olan bir mekânı aşabilme (ya da özgürleşebilme) hayalidir (Sevinç, 2014: 155). Ancak bu aşma aynı zamanda o mekânı peşinde götürmeyi de içermektedir. 
Katılımcıların anlatılarına göre Trabzon 'hayattır', 'yaşamın' ta kendisidir. Doğdukları, büyüdükleri ve yaşadıkları yer olan Trabzon onlar için özel bir yerdir. Bu anlamıyla Trabzon, katılımcıların ifadesiyle bir 'evdir'. İnsanın ilk evreni olan ev dünyadaki korunaklı bir köşeyi imlemektedir (Bachelard, 2013: 34, 37). Varoluşunun temelini oluşturan bir mekân olarak ev, bireyler ve gruplar için korunaklı bir 'merkez' ve kimlik sağlamaktadır (Relph, 1976: 41; Dovey, 1985: 36-40). Ev kişinin kendisi olabildiği tanıdık, bildik bir mekândır (Cresswell, 2008: 24). Ayağında ayakkabısı olmadan sokaklarında yürümekten gocunmayacağını söyleyen K1 (erkek, 26 yaş, doktora öğrencisi) Trabzon'un evi olduğunu aşağıdaki sözlerle anlatmaktadır:

26 senelik 27 senelik hayatımın tamamını gözden geçirdiğimde Trabzon bir ev, bir ev kadar küçük. Trabzon'un her sokağ1, o sokakta görmüş olduğun her insan bir akraban. Kendini güvende hissetmen noktasında bu kadar rahat, bu kadar böyle elin cebinde dolaşabileceğin başka bir şehir daha yok... (Küçükken) Avni Aker'e maça gidiyorsun, tanınmana şey yapmana gerek yok. Herhangi bir kişi "abi beni önüne alsana" dediğinde o sana "ne münasebet ne diyorsun" falan demiyor. "Tabii oğlum herhalde yani küçüksün turnikeye sığarsın, gel tabii ki." Çünkü insanlar senin gözünde "aa işte yabancı m1, zarar verir mi sana, vermez mi?" şeklinde düşünebileceğim bir insan topluluğu yok.

Katılımcıların kendilerini evlerinde hissettikleri yerdir Trabzon, çünkü oradaki herkes bir yabancı değil, kendisinden bir parçadır. Dolayısıyla bu kişilerden zarar gelmesi mümkün değildir ve güvene dayalı ilişkilerin varlığı kente olan aidiyeti pekiştirmektedir. K4 (kadın, 20 yaş, üniversite öğrencisi)'ün de yukarıdaki anlatıyı desteklediği gibi, Trabzon'un sadece bir yeri değil, her yeri ev gibidir. Herkesin birbirini çok iyi tanıdığı, her bir köşesini avuçlarının içi gibi bildikleri bir mekândır, Trabzon. Düzenli olarak karşılaşılan insanlar artık birbirlerine tanıdık gelmektedir. Gündelik rutin içerisinde gerçekleşen bu karşılaşmalar ise, güçlü bir mekân duygusu yaratmaktadır (Seamon, 1979: 56-57). Yakınlık, benzerlik ve tanınırlık mekâna kök salmayı sağlamaktadır (Relph, 1976: 37).

Bununla birlikte, Trabzon'dan uzun süreler ayrı kalmamış olan derinlemesine mülakat katılımcıları için Trabzon bir nevi kaderdir. Önceden ulvi anlamlar yüklediği Trabzon'un kaderden ibaret olduğunu K1 (erkek, 26 yaş, doktora öğrencisi) aşağıdaki sözlerle anlatmaktadır:

\footnotetext{
On sene öncesinde sordular mı "tabii ki Trabzonlular, Trabzonlu olmak ayrıcalıktır, Trabzon bambaşkadır, Türkiye'de Trabzon gibisi var mı, işte Trabzonlular işte şöyle yapmıştır, böyle yapmıştır, işte bilim adamı çıkarmıştır, sanatçı çıkarmıştır, asker çıkarmıştır, polis çıkarmıştır.” İşte bunları çok aşırı şekilde yani anlatmak isterdim. Yani karşımdaki insanı Trabzon'un bir numara olduğuna ikna etmek isterdim. Daha yaşım küȩükken. Şuan sadece evet ben Trabzonluyum, çünkü bu bir gerçek. Ben 26 yıldır burada yaşıyorum. Görmüş olduğum birçok şeyi burada gördüm, yaşadım. Ve buranın kültüründen beslendim. Ve dolayısıyla gidip de farklı bir şey söylemem dikkat çekmek için yapılmış olan sahte bir söylem olur yani. Doğrusu bu, Trabzon.
}

Yukarıdaki anlatıda katılımcının kenti deneyimleyen başkalarıyla birlikte oluşturduğu ortak anlamın zamanla kendisi için değiştiği görülmektedir. Çünkü insan ve mekân arasındaki etkileşim insanın hayat döngüsü boyunca devam etmektedir ve yaşam ilerledikçe diğer tüm durumlarda olduğu gibi insanın yaşadığı mekânla ilgili düşünceleri, duyguları, değerleri, hatıraları ve tutumları da zaman içinde değişmektedir (Proshansky, 
1978: 156). K1 de aldığ1 lisansüstü eğitiminin sosyal çevresini değiştirdiğinden ve buna bağlı olarak Trabzon'la kurduğu duygu yüklü ilişkinin coşkusunun eskiye nazaran değiştiğinden bahsetmektedir. $\mathrm{Bu}$ değişimin sonunda Trabzonlu olmak onun için bir lütuf ya da ayrıcalık olmaktan çıkmıştır. Trabzon onun için kaderden ibarettir, tıpkı Trabzonspor'un çoğu katılımcı için bir yazgı olması gibi. Trabzon, K1 için gerçek hayattır. Çocukluğunun geçtiği bu mekân geçmişten izler taşımaktadır, gündelik hayatının geçtiği yerdir, anlamlarla yüklüdür (Tuan, 2001: 145). Çocukluğundan beri deneyimlediği bu mekân onun kimliğinin oluşumuna katkı sağlayan unsurların bulunduğu yerdir. Bu nedenle onun için Trabzon bir aidiyeti imlemektedir. Diğer taraftan, ona göre bu aidiyet gerçekliğin kabulünü gerektirmektedir. Gerçeklik Trabzon'dur.

Trabzon bir kaderdir, ancak bu kader bir zaman sonra aşk olarak tanımlanmaktadır. K5 (erkek, 24 yaş, A101 çalışanı) bir arkadaşı ile birlikte Trabzon'a duyduğu aşka dair arabesk-rap bir şarkı yapmış ve YouTube kanalı aracılığıyla şarkıya çektiği klipin geniş kitlelere ulaşmasını sağlamıştır. İki ayrı beste ve iki ayrı klip bulunmaktadır. Söz konusu videolar defalarca izlenmiş ve videoların altına yapılan yorumlarla birlikte analiz edilmiştir. Videolarda, kullanılan formalar ve atkılarla Trabzonspor vurgusu ön plandadır. Çünkü bordo-mavi renkler aynı zamanda Trabzon'u simgelemektedir. Dolayısıyla Trabzon'a yönelik olan aşkı pekiştiren unsurlardan biri Trabzonspor'dur. İlk videoda mekân olarak daha çok sahil, ikinci videoda ise stadyum kullanılmaktadır. 2014 yılında yayınlanan Aşk-1 Trabzon $2^{1}$ videosunun altına yorum yapan gurbetçilerden biri bu şarkıyı her dinlediğinde Trabzon'daki akrabalarını hatırladığını ve Trabzon'a büyük özlem duyduğunu belirtmektedir.

\begin{abstract}
(...) Trabzon'umu anlatayım, sesini kes de kulak ver. Aşk dedun mi orda dur da, bordo mavi sevgidur (...) Avni Aker dedin mi kulaklarda bordo mavi. Bir kor ateş yanar da kalbimin ortasında. Tek kazılı bir tarih vardır, 1967. Trabzonspor mu? İşte o zaman kalp durur. Bütün şehir tek bir yürek, tek bir sesle yankılanır. Şimdi diyorum bordoyu, siz de deyin maviyi, oynayın da kolbastiyi, coşturun bu sevdayi. Gir koluma dolaşalım, Beşirli'den başlayarak. Ayasofya, Yenimahalle, Faroz'a doğru gel benumle. Yorulduysan laz kizi Ganita'da oturalum. Bir bakış at bana Trabzon'u sallayayim. Vazgeçilmez bir cümledir "Bize her yer Trabzon." Boş laflara gerek yok, bu şehir aşkı Trabzon'da buldu (...) Habura neresidur? Habura Trabzon'dur. Oynayın ha uşaklar, bizim oyun kolbastidur. Coşturun Trabzon'i oynayin kolbastiyi. Geri dur laz kizi, yıkar geçirur bizi (Aşk-1 Trabzon 2) (...)
\end{abstract}

Alıntının başında Trabzon'a sahiplik belirten iyelik eki eklenmiştir. Benim 'Trabzon'um' ifadesi sahipliğin yanında (mülkiyet sahipliği ile karıştırılmamalıdır) anlatıcı ile Trabzon arasındaki bağlantıyı ifade etmektedir. Bu ifadede kullanılan iyelik eki 'Ben' ve 'Sen'in başka mekânlara ait olduklarını göstermektedir (Cresswell, 2008: 1). Burada kendileme söz konusudur. İnsanlar bir yerle psikolojik, toplumsal ve kültürel bağlar kurduğunda o yeri kendisinin kılmakta ve anlamlandırmaktadır (Werner vd., 1985: 5). Kişilerin bir sokağa, mahalleye ya da kente sahip olması elbette mümkün değildir, ancak kendilerinden bir şeyler katmaları mümkündür. Böylece o yeri kendileyen bireyler aynı zamanda ortak bir kimlik de inşa etmektedir (Göregenli, 2010: 124).

Trabzon'a duyulan bu sevgi gençlerin kenti terk etmelerini de engellemektedir. Çünkü gençler kök saldıkları bu mekânda kendilerini içeride hissetmekte, dolayısıyla dışarıya

1 Videoyu izlemek için bakınız: Aşk-1 Trabzon 2. https://www.youtube.com/watch?v=eBdgUyx4dRQ. Son erişim tarihi, 10.01.2018. 
çıkma konusunda tedirgin olmaktadır. Trabzon'a duyulan hasreti 'mübarek toprakları' görmek için umreye gitmenin hasretini çekmeye benzeten K8 (kadın, 20 yaş, satış danışmanı) da Sakarya'dan Trabzon'a doğru olan eve dönüş yolunda duyduğu heyecanı aşağıdaki sözlerle anlatmaktadır:

Otobüste geliyoruz. Allah'ım sabah olsa diyorum. Samsuna geldim bir nebze içim rahatladı ama tam rahatlamıyor için. Şoförümüz de mesela bizim Beşikdüzü Trabzonluymuş. Abla diyor Samsun’u görüyorum sanki Trabzon'a ayak basmış gibi. Yok abi dedim. Sen öyle olabilirsin, ben Trabzonluyum Trabzon'da olmadan sevinmiyorum. Giresun, Beşikdüzü'nü de Trabzon'dan saymıyorum açıkçası. Böyle gidiyorsun gidiyorsun, böyle bir şey, Akçaabat'ı görüyorsun, şurana (kalbini işaret ediyor) bir öküz oturmuş oluyor. O kalkıyor. Böyle bir nefes alıyorsun. Trabzon çok çok farklı bir yer.

Görüldüğü üzere, kente dair oluşturulan anlatılar aslında bir yolculuk anlatısıdır da. Bu anlatı, bir yerden bir yere, bir zamandan başka bir zamana gidilirken oluşturulmaktadır. Çünkü anlatının oluşabilmesi harekete bağlıdır (de Certeau, 2008: 214-215). Mekânlar arasındaki mesafelerde yapılan yolculuk onları birbirine bağlamakta ya da birbirinden ayırmaktadır (Tuan, 2001: 12). Trabzon'dan gitmek demek dışarıya gitmek demektir. Trabzon'da bulunmak ise içeride olmaktadır. Bu anlamıyla Trabzon gençler nezdinde bir merkez olarak inşa edilmekte ve yolculuklar hep bu merkezden uzağa doğru yapılmaktadır (Seamon, 1979: 73). İnsan geziye çıktıktan sonra eve dönmeyi arzulamaktadır. Söz konusu arzu da 'bura'nın inşasına bağlıdır (Schick, 2000: 23). 'Bura'ya dönebilmek için dışsallaştırılmış bir 'Ora'ya ihtiyaç duyulmaktadır. Yani benliğin oluşumu 'Ora' dan çıkıp ‘Bura’ya dönmekle tamamlanmaktadır (Bachelard, 2013: 257).

Anlatılarında katılımcılar dışarısı (Ora) ve içerisi (Bura) arasında keskin bir ayrıma işaret etmektedir. İçeridelik hissi Trabzonlu gençlerin kente olan aidiyetlerini kuvvetlendirmektedir. Böylesi bir kentte büyüyen (toplumsallaşan) Trabzon gençleri aynı zamanda Trabzon üzerine üretile gelen mitsel anlatıyı da öğrenmekte ve yeniden üretimine katkı sunmaktadır.

\section{Mitselleştirilen Mekân: 'Delikanlı’ Trabzon}

Trabzon'da yaşayan gençlerin mekâna özgü mitsel anlatılar oluşturdukları görülmektedir. $\mathrm{Bu}$ anlatılar sosyo-kültürel pratik/söylemin bir kurgusudur ve dışlama mekanizmalarının işlerliğini kolaylaştırmaktadır (Paasi, 2003: 480). Gerçeği pek de yansıtmayan mitler bilginin tam olmadığı durumlarda ortaya çıkmaktadır (Tuan, 2001: 85-86). Söz konusu mitler cemaatin sembolik inşası için içsel olarak oluşturulmuş hikâyelerden meydana gelmektedir (Shields, 1988: 370). Mitsel alan içerisinde, birlikte yaşayan grup üyeleri arasında ve mekân ile bir özdeşleşme gerçekleşmekte, mekâna sembolik anlamlar yüklenmektedir. Böylece mitsel anlatılar sayesinde birey ile grup ve mekânı arasında bir bağ kurulmaktadır (Duncan, 1985: 137-147). Duygusal anlamda bağlanılan kent de mitselleştirilmektedir. Bir kent tüm duyularla kavranmakta (koklayarak, işiterek, dokunarak, izleyerek, tadına bakarak) ve arzu nesnesine dönüşmektedir. Tam da bu noktada hayali ve kurgusal bir kent imajı oluşturulmaktadır: Kent yüceltilmektedir (Bilgin, 2013: 132).

Gençlerin bir takım tarihsel olaylar üzerinden kente özgü mitler oluşturdukları ya da mevcut mitlerin yeniden üretimine katıldıkları görülmektedir. Ancak kente özgü tarihsel mitin oluşumu tarih bilincinin gençlerde olmayışıyla belirmektedir. 
Kişilerin tarih bilincine sahip olması onların (bilimsel olması gerekmese de) tarih bilgisine sahip olmasına bağlıdır. Ancak salt tarih bilgisi yeterli değildir. Bu bilginin toplumla, sorumluluklarla, kültürle, ideolojilerle ve özneler arası ilişkilerle yoğrulması gerekmektedir. Ancak bu şekilde tarih bilinci oluşabilir (Tekeli, 2013: 109). Derinlemesine mülakat katılımcıları bölge tarihleri hakkında detaylı bilgiye sahip değillerdir, dolayısıyla kente dair bir tarih bilinci tam anlamıyla oluşmamıştır. Çok azı Trabzon, aile ve köylerine ilişkin tarihi bilgiye sahip olduğunu belirtmiştir. Tarihi olarak ifade ettikleri olaylar da bu zamana kadar söylene gelen kurgulardan ibarettir. Fatih' in fethettiği, Yavuz'un yönettiği, Kanuni'nin doğduğu, Atatürk'ün de ayak bastığ1 kent olarak özetlemektedirler, Trabzon tarihini. Söz konusu olaylar mitselleştirilerek anlatılmaktadır. Mesela Fatih Sultan Mehmet, "Trabzon fethedilmeden İstanbul'un fethi tamamlanmamıştır” demiş; Atatürk de Samsun'a ayak bastığında "en önde Trabzonluların olduğunu gördüğünden gurur duyduğunu" söylemiştir. Bununla birlikte, Trabzon aynı zamanda milli mücadelenin öncülüğünü yapan bir ildir. Örneğin, Trabzon Lisesi Çanakkale Savaşı'nda mezun verememiştir. Katılımcılar söz konusu tarihsel olayların ne zaman ne şekilde gerçekleştiği hakkında ise bilgi verememekte, sadece üstten kurgulanan bir söylemi tekrar etmektedir. $\mathrm{Bu}$ kurgulanmış anlatılar aslında bir mekân olan Trabzon'un da kimliğini oluşturmaktadır. Tarihin mekânlardan nasıl bahsettiği bu anlamda önemlidir (Massey, 1995: 186). Katılımcılar Trabzonluların Türkiye Cumhuriyeti'nin temel taşı olduğuna yönelik resmi tarih söylemine paralel bir anlatı oluşturmaktadır. Trabzonlular bu nedenle ayrıcalıklıdır. Kıbrıs Harekâtı'nda da Trabzonlulara önemli görevler düşmüştür. Kıbrıs’ın millileştirilmesi için özellikle Trabzonluların oraya yerleştirildiğinden bahsedilmektedir:

Şöyle de bir şey var, benim bildiğim kadarıyla, zaten mesela Kıbrıs Harekâtı olduktan sonra Kıbrıs'ı özellikte Doğu Karadenizli, özellikle Trabzon insanını yerleştirmişler. Mesela ben çok duyuyorum niye bu kadar çok Trabzonlu var Kıbrıs’ta, ben mesela çok tartışırdım. Oraya özellikle Trabzon'un insanını seçtiler, orayı Türkleştirmek, milliyetçileştirmek için. Milliyetçileştirmek için orayı özellikle bizim insanımızı seçtiler (K11, erkek, 22 yaş, üniversite öğrencisi).

Kente dair söz konusu duygunun sürekliliğini sağlayan bazı tarihsel olaylardan da söz edilmiştir. Rus işgali Trabzon için bir travmadır ve ilk anlatılan tarihsel olaylardandır. Bu olayın hafızalarda canlı kalmasını sağlayan önemli unsurlardan biri, her yıl 24 Şubat'ta düzenlenen Trabzon'un kurtuluşunun kutlandığı etkinliklerdir. 24 Şubat 1918 tarihinde Osmanlı birlikleri Trabzon’u Ruslardan geri almıştır (Hür, 2010: 150). Bu nedenle 24 Şubat tarihi Trabzonlular için oldukça önemlidir. Derinlemesine mülakat katılımcıları da, 24 Şubat'ta düzenlenen kutlamaların Trabzon'u simgeleyen önemli etkinlikler arasında olduğunu ifade etmiştir. Bu türden anmalar geçmiş hatıraların gelecek nesle aktarılmasını kolaylaştırmaktadır. Aynı gün ve mekânda her yıl gerçekleştirilen anma ritüelleri geçmişin teatral bir şekilde tekrarını ve bugünde yeniden kurgulanmasını sağlamaktadır. Böylece söz konusu tarihi olay hafizalarda canlı tutulabilmekte, mekânsal ve zamansal bağ güçlü kalabilmektedir (Assman, 2001: 42-43, 60-62).

24 Şubat'ta gerçekleştirilen söz konusu etkinlikler ortak bir milli duygunun da oluşmasını sağlamaktadır. Bu yıl düzenlenen 24 Şubat etkinliklerinde 18 Şubat 2018 tarihinde Eren Bülbül adına halk koşusu düzenlenmiştir. Eren Bülbül, Trabzon’un Maçka ilçesinde PKK militanlarının köydeki evlerine girerek erzak çaldığını jandarmaya 
haber vermiştir. Bunun ardından, bölgeyi bildiği gerekçesiyle, 15 yaşında olan Eren Bülbül'ü yanına alan Jandarma bölgede bir keşif yapmaya gitmiştir. 11 Ağustos 2017'de gerçekleşen bu olayda çatışma çıkmış ve Eren Bülbül şehit olmuştur. 2018 yılında 38.'sinin düzenlendiği Uluslararası Trabzon Yarı Maratonu "Eren için koşuyoruz", "İyi ki varsın Eren” sloganlarıyla gerçekleştirilmiştir. Bununla birlikte, Eren Bülbül ve aynı çatışmada şehit düşen Jandarma Astsubay Başçavuş Ferhat Gedik’in isimleri Ortahisar-Maçka yolundaki tünellere verilmiştir. Trabzon'da neredeyse bütün üst geçitlerde şehit isimlerini görmek mümkündür. Şehit isimleri ile donatılan söz konusu geçitler, tüneller ve anma etkinlikleri sürekli olarak şehitleri hatırlatmakta ve Trabzonlularda milliyetçi duygunun canlı kalmasını sağlamaktadır². Bu türden yerler, anıt özelliği de sergilemektedir. Söz konusu anıtta cisimleşmiş olan hafiza (milliyetçi ideoloji ile birlikte) ise, gelecek kuşaklara aktarılabilmektedir. Çünkü toplumsal hafıza ancak mekânsallaştığı, somut bir bedene sahip olduğu ölçüde canlı kalabilmekte, zamanı durdurmakta ve unutmayı engellemektedir (Bachelard, 2013: 39; Nora, 1997: 34-38). Her yıl aynı zamanda ve aynı yerde tekrarlanan anma etkinlikleri de toplumsal hafızanın canlı kalmasını sağlamaktadır (Connerton, 1999: 72).

Tarihsel olaylara bağlı inşa edilen hafızanın yanında, katılımcılar, özellikle Trabzon'un güvenli bir yer olduğu konusunda da çeşitli mitler üretmektedir. Gençler Trabzon'u güvenilir bulmaktadır. Anlatılara göre "hiç kimse gelip Trabzon'da terör eyleminde bulunamaz, çünkü zaten herkesin evinde silah vardır ve herkes korkmadan teröristlerle çatışmaya girebilir." Keza Maçka'da terör saldırısına ${ }^{3}$ uğrayan polisleri korumak için halk eline silahları almış ve teröristlerin peşine düşmüştür. K9 (erkek, 19 yaş, berber çırağı) Trabzon'un Türkiye'nin en güvenilir ili olduğunu şu sözlerle anlatmaktadir:

Anket yapılmış herhalde, Trabzon Türkiye'nin en güvenilir ili seçilmiş, diye biliyorum ben. Hiç öyle duydunuz mu? Ben geçen bir yerde okudum, öyle gördüm. Doğru mu yalan mı bilmiyorum ama gördüğümüz kadarıyla doğru. Yani hiç ne terör olayları oluyor ne başka bir şey oluyor, ne üniversitelerimizde sıkıntılar oluyor. Bilmem oluyor mu, siz daha iyi bilirsiniz? Öyle işte, güzel güvenilir bir yer yani. O yüzden çok denediler işte Trabzon'u Türkiye'nin kalesi gibisinden, Trabzon'da bir şey yapabilsek daha iyi olur falan diye. Mesela Maçka'ya kadar gelebildiler, Maçka'dan sonra inemediler aşağıya. Bayağı olaylar oldu. 6-7 tane terörist vardı Maçka'da. Muhtar yardımcı oluyormuş bunlara. Köy muhtarı. Hem köy muhtarını linç ettiler. Bildiğiniz gibi değil ya. Biz buradan silahlarla çıktık Maçka’ya.

2 Eren Bülbül'ün şehit haberinin ardından Trabzonluların sosyal medyada oldukça fazla paylaşımlarda bulundukları gözlemlenmiştir. Söz konusu paylaşımlar, Eren Bülbül'ün daha önce yapmış olduğu bir sosyal medya paylaşımına referansla \#İyikiVarsınEren etiketi ile yapılmışlardır. Trabzonspor Kulübü, statta bütün taraftarların ayakta asker selamı verdiğini gösteren fotoğrafla birlikte "Yiğidimiz Eren hep 15 yaşında... Unutulmayacaksın" sözlerini sosyal medya hesabından paylaşmıştır. VİRA grubu da tribünlerde açmak üzere Eren Bülbül için pankartlar hazırlamıştır. Pankartlarda şunlar yazmaktadır: "Tarihin dilinden düşmez bu destan. Nehirler Gazidir, dağlar Kahraman (Gazi ve Kahraman kelimeleri kırmızı renk ile yazılmıştır). Her taşı yakut olan bu vatan, can verme sırrına erenlerindir (Orhan Saik Gökyay şiiri). Ferhat gibi yüreği olup Şehadete Erenler! (Ferhat ve Eren isimleri kırmızı renkle yazılmıştır) Selam olsun.”

3 Temmuz 2016 tarihinde Maçka'da yol kontrolü yapan polis ekiplerine saldırı gerçekleştirilmiştir. Saldırıda 3 polis şehit, 4 polis gazi, 1 vatandaş da yaralanmıştır. Olayın hemen ardından ormanlık alana kaçan teröristleri yakalamak için operasyon başlatılmış, orada yaşayan vatandaşlar da silahlarıyla polise yardım etmek için ormanlık alana girmiştir. Halkın silahlarıyla teröristleri yakalamaya çalışması medyada sıklıkla vurgulanmıştır. Bkz.: www.61saat.com. Son erişim tarihi, 10.03.2018. 
Yukarıdaki anlatıda Trabzon Türkiye için bir kale olarak nitelendirilmektedir. Tıpkı tarihsel süreçte İstanbul'un fethinin Trabzon'un fethi ile tamamlandığını kurgulayan mitte olduğu gibi, Trabzon bu anlatıda da mitselleştirilmekte ve Türkiye'nin kalbi, son kalesi olarak tanımlanmaktadır. Trabzon düşerse Türkiye'nin parçalanacağ1 inancı yaratılmaktadır. Çoğu Trabzonludan duyulabilecek bu sözler, aslında onların milliyetçi tutumlarının da göstergesidir. Söz konusu milliyetçilik hem şehir hem de ülke milliyetçiliğidir. İnanca dönüşmüş bu mitsel anlatı, bir Trabzonlunun kendisini ortak duyguyu paylaştı̆̆ı grupla ve o grubun mekânı ile özdeşleşmesini sağlamaktadır. Mitler aracılığıyla bu grup, mekâna sembolik anlamlar yüklemektedir (Duncan, 1985: 138). Anlatıda aynı zamanda Trabzonlular kahramanlaştırılmaktadır. Kahramanlaştırılan elbette erkeklerdir. Militarize edilmiş Trabzon erkekleri kahraman koruyucular olarak kurgulanmakta ve hegemonikleştirilmektedir. Silahını alan her bir Trabzonlu erkek, teröristlerin Maçka dağlarından şehre inmesine izin vermemiş, onlara destek olan vatan haini köy muhtarını da cezalandırmıştır. Şehirde terörist saldırıların olmaması Trabzonlu erkeklerin varlığıyla ilişkilidir. İşte böylesi cesur erkeklerin bulunduğu Trabzon'da insanların kendilerini güvende hissetmemeleri mümkün değildir. Öyleyse Trabzon'da erkekliğin ataerkil değerler üzerinden hissedildiğini söylemek yerinde olacaktır. Saldırganlık, şiddet, sınırsızlık, savaşçılık, zafer ve kahramanlık gibi eril öğeler Trabzonlu erkekleri anlatmaktadır (Bozok, 2013: 197).

Benzer şekilde K10 (erkek, 19 yaş, berber çırağı) da "Karadeniz'in en güvenilir yeri” olan Trabzon'u Karadeniz' in “delikanlı” şehri, “Türkiye’nin emniyet sbobu” olarak tanımlamaktadır. Trabzonlu olmanın bizatihi kendisinin eril öğeler içerdiğini gösteren anlatı burada da belirmektedir. K6 (erkek, 19 yaş, üniversite öğrencisi) Trabzonlu olmayı şöyle tanımlamaktadır:

Bizim Trabzonspor taraftarının bir lafı vardır: "Dünyada Türk olmak gibiydi, Türkiye'de Trabzonsporlu olmak." Yani öyle bir şey yani Trabzonlu olmak. Nasıl diyeyim insanın erkek evladı olarak erkekliğini kabartan bir şey. Yiğitlik, mertlik açısından gerekirse kadınını dinlemek açısından. Asalet gerektirir. Vallahi şimdi yani Anadolu insanı gibi sıcak, cana yakın, Karadenizli olmasından dolayı hiddetlenebilen.

K1 (erkek, 26 yaş, doktora öğrencisi) de aynı söylemi tekrar etmektedir:

Ha şu güvenli bir yer evet. Şöyle bir klişe vardır, Trabzonluların çoğu da bundan böbürlenir. İşte Trabzon anaların "oğlum kendine işte dikkat et, bak işte kolla kendini dediği yer" değil de, "kimseye musallat olma" dediği yerdir. Yani. Bu ne demek? İşte Trabzon'da kişilerin hani özgüveni yüksektir, Trabzon'daki birine zaten kimse zarar veremez. Ha o birine zarar vermesin. Yani. O yönden korumacı içgüdü.

Anlatılarda Trabzonluların en önemli özelliği birlikte yaşadığı insanlarla bir bütün olabilmesi ve ülkeyi koruyabilmesidir. Burada çok kuvvetli bir cemaat duygusu hâkimdir. Söz konusu duygu yer duygusunun da oluşmasını sağlamaktadır. Ait oldukları cemaatle özdeşleşme beraberinde mekânla özdeşleşmeyi getirmektedir (Hummon, 1992: 262-265). Trabzonlu gençlerin ait oldukları mekânı birlikte deneyimledikleri topluluğa dair idealize edilmiş anlatılar oluşturdukları görülmektedir. "Ülkeye bir şey olmayacaksa Trabzonlular sayesinde olmayacağını” söyleyen K4 (kadın, 20 yaş, üniversite öğrencisi), Trabzonluları Türkiye'nin her yerine yayılmış "koruyucu melekler” olarak tanımlamaktadır. K12 (kadın, 16,5 yaş, lise öğrencisi) de Trabzonluları vatanına milletine düşkün insanlar olarak bilmektedir. Trabzonluların milliyetçiliği ve vatanseverliği ile övünen K7 (erkek, 22 yaş, 
üniversite öğrencisi) ise, Türkiye'nin T'sinin Trabzon'un T'si olduğunu söylemektedir'. Trabzonlu olmaktan gurur duyulmasının önemli nedenlerinden biridir 'milliyetçi tutum'.

Bununla birlikte, Trabzonlu olmanın kendilerine belli alanlarda ayrıcalık sağladığını ifade eden katılımcılar da olmuştur. Bu ayrıcalık Trabzon'un güvenli olmasına paralel olarak, Trabzonlu gençlerin de güvenilir kişiler olmasından kaynaklanmaktadır. Söz konusu ayrıcalık daha çok erkekler tarafından dile getirilmiştir. Bu ayrıcalıklı hal onların erkeklik rollerini eksiksiz yerine getirmesine bağlıdır. Anlatılara göre, komutanlar askerde dahi Trabzonlulara ayrıcalık tanımaktadır (K13, erkek, 21 yaş, üniversite öğrencisi), çünkü Trabzonlu genç erkekler ülkenin savunmasında cesurca görev alabilecek güvenilir kimselerdir ${ }^{5}$. Trabzon'un eril bir kent görünümüne sahip olmasının bir göstergesi olan bu anlatı, Trabzonlu olmanın da eril öğeler içerdiğini en azından eril öğeleriyle ön plana çıktığını göstermektedir. Bu eril öğelerle ön plana çıkan Trabzonluluk, genç erkekler için bir gurur kaynağı olmaktadır. Trabzonlu (Trabzon erkeği) milliyetçi, muhafazakâr, dindar ve ailevi değerlere önem veren bir tipoloji olarak belirmektedir (Bozok, 2016: 413-414).

Gençlerin kente olan aidiyetlerini pekiştiren bir diğer husus da Trabzonspor taraftarlığıdır. Sonraki bölümlerde Trabzonspor taraftarlığının gençlerin kente olan aidiyetleri ve şehir milliyetçiliği üzerindeki etkisinden bahsedilecektir.

\section{Trabzonspor Taraftarlığı, Toplumsal Hafıza ve Mekân}

Futbol, taraftarlarına kendilerini ifade etme, bir gruba ait olma imkânı tanımaktadır. Bir gruba olan aidiyet mekâna olan aidiyeti de güçlendirmektedir. Birbirine benzeyen bireylerden oluşan bir topluluğa üye olmak, o topluluğun bulunduğu mekânla olan bağını da kuvvetlendirmektedir. Topluluk ve mekân arasındaki bu ilişki kimliğin oluşmasında etkilidir (Relph, 1976: 33-34). Trabzonspor taraftarı olmanın da mekâna dayalı böyle bir grup aidiyeti yarattığı; katılımcıların Trabzon'a olan bağlılığını artırdığı görülmektedir. Trabzon'da yaşayan gençlerin büyük bir çoğunluğu Trabzonsporludur. Ankete katılan katılımcıların \%69,1'i Trabzonspor dışında başka bir takım tutmadığını, \%14,3'ü Trabzonspor'u ve başka bir takımı birlikte tuttuğunu, \%15,6'sı Trabzonspor taraftarı olmadığını ve başka bir takımı tuttuğunu belirtmiş̧tir. Katılımcıların \%1'i (4 kişi) ise takım tutmadığını ifade etmiştir. Kadın katılımcılarda (\%21,2'si) Trabzonspor dışında başka bir takımı tutma oranı erkek katılımcılara $(\% 10,3)$ göre yüksektir. Erkeklerin \%75,4'ü, kadınların da \%62,4'ü Trabzonspor dışında başka bir takım tutmadığını ifade etmiştir.

4 Benzer tespitler Bayram Sevinç tarafından da yapılmıştır. Sevinç, "Bize her yer Trabzon" metaforunu bazı durumlarda Trabzonluların kendilerini milliyetçi, yani Türkiye’nin bütün illerini Trabzon kadar kendi memleketleri olarak görmeleri şeklinde yorumladıklarını belirtmektedir. Trabzonlu milliyetçi ve vatansever olduğu için de Trabzonlu olmak bir ayrıcalıktır. Bkz.: B. Sevinç (2014). Trabzonluluk Kimliği: Bir Şehrin Ruhu. Trabzon: Serander Yayınları, 180-181, 187.

5 Hatta erkekliğin öğrenilmesinin mahalle tedrisatında gerçekleşmesine bağlı olarak, Farozlu ya da Ayasofyalı bir genç olmak kentte bu ayrıcalıklı durumu artırmaktadır (K14, erkek, 19 yaş, üniversite öğrencisi; K15, erkek, 22 yaş, üniversite ögrencisi). 
Tablo 1

Trabzon Dişında Başka Bir Takım Tutma

\begin{tabular}{|c|c|c|c|c|c|c|}
\hline & & 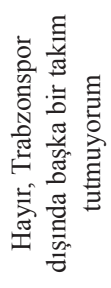 & 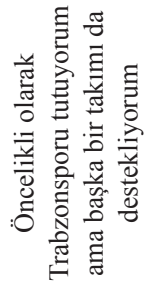 & 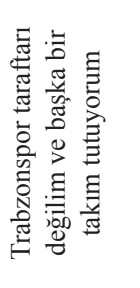 & 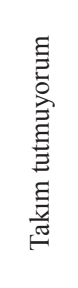 & $\frac{\Xi}{\frac{\Xi}{0}}$ \\
\hline \multirow{2}{*}{ Kadın } & Sayı (Kişi) & 118 & 30 & 40 & 1 & 189 \\
\hline & Cinsiyet \% & $62,4 \%$ & $15,9 \%$ & $21,2 \%$ & $0,5 \%$ & $100,0 \%$ \\
\hline \multirow{2}{*}{ Erkek } & Sayı (Kişi) & 153 & 26 & 21 & 3 & 203 \\
\hline & Cinsiyet \% & $75,4 \%$ & $12,8 \%$ & $10,3 \%$ & $1,5 \%$ & $100,0 \%$ \\
\hline \multirow{2}{*}{ Toplam } & Sayı (Kişi) & 271 & 56 & 61 & 4 & 392 \\
\hline & $\%$ & $69,1 \%$ & $14,3 \%$ & $15,6 \%$ & $1,0 \%$ & $100,0 \%$ \\
\hline & \multicolumn{3}{|c|}{ Pearson Chi-Square } & ,011 & & \\
\hline
\end{tabular}

Trabzonspor taraftarlığının kentle özdeşleşmeyi sağladığını gösteren anlatı, Trabzonluların Trabzonspor dışında başka bir takım tutmasının mümkün olmadığıdır. Söz konusu anlatı mikromilliyetçiliğin futbol aracılığıyla pekiştiğini göstermektedir. Ulusal ve yerel kimliğin yeniden üretiminde futbolun da önemli bir yeri bulunmaktadır. Bazı kentler futbol takımlarını 'bayraklaştırmakta' ve bölgesel öncülüğünü ya da mücadelelerini (İstanbul'a karşı Anadolu'yu temsil etme gibi) kent takımı üzerinden sembolleştirmektedir (Gökaçtı, 2008: 298). Trabzon da bu kentlerden biridir. Ankette yer alan "Bir Trabzonlu Trabzonspor Kulübü'nden başka takım tutmaz" ifadesine katılımcıların \%41,7'si ‘kesinlikle' katıldığını, \%15,1'i katıldığını belirtmiştir (Toplamda \%56,8). Trabzonlu bir kişinin Trabzonspor Kulübü'nden başka bir takım tutabileceğine inananlar ise katılımcıların \%31,2'sini oluşturmaktadır. Anket katılımcılarının Trabzonlu birinin bir futbol takımı tutacaksa Trabzonspor'u tutması gerektiğine inandığı görülmektedir.

Tablo 2

“Bir Trabzonlu Trabzonspor Kulübü'nden başka takım tutmaz”

\begin{tabular}{|l|c|c|}
\hline Kategori & Sayı (Kişi) & Geçerli \% \\
\hline Kesinlikle katılmiyorum & 80 & $20,50 \%$ \\
\hline Katılmıyorum & 42 & $10,70 \%$ \\
\hline Ne katıliyorum ne katılmiyorum & 47 & $12,00 \%$ \\
\hline Katıliyorum & $\mathbf{5 9}$ & $\mathbf{1 5 , 1 0 \%}$ \\
\hline Kesinlikle katıliyorum & $\mathbf{1 6 3}$ & $\mathbf{4 1 , 7 0 \%}$ \\
\hline Toplam & 391 & $100,00 \%$ \\
\hline
\end{tabular}

Derinlemesine mülakat katılımcıları da anket verileriyle benzer şekilde, Trabzonlu oldukları için Trabzonspor taraftarı olduklarını belirtmişlerdir. Hatta Trabzonsporlu olmak aileden gelen bir mirastır. Katılımcılar Trabzonlu olup Trabzonspor'u desteklememeyi ise, ihanet olarak nitelendirmektedir. Bir Trabzonlunun Trabzonspor'dan başka bir takım 
tutması mümkün değildir; İstanbul takımları yerine kendi kentinin takımını tutması gerekmektedir. Benzer tespitler Sevinç (2014: 237-238)' in çalışmasında da yapılmıştır.

Trabzonlu olduğum için Trabzonsporluyum. Trabzon'un suyunu içiyorum, Trabzon'un ekmeğini yiyorum, Trabzon'da yatıyorum, neden yaşadığım şehrin takımını tutmayayım. Mesela Rize'ye gittim, kötülemek gibi değil ama Rize'nin birçok insanı, kimse Çaykur Rize'yi tutmaz. Ama takımınız var Süper Lig'de oynuyor (K9, erkek, 19 yaş, berber çırağı).

Başka bir takım tutmayı düşünmedim evet. Çünkü kendi şehrimin bir sporu var, benim onu tutmam gerekiyor. Yani ona ilgi göstermem gerekiyor ki şehrimizi daha güzel tanıtabilelim. Hani daha bir başarılı olsun her yönden (K18, kadın, 21 yaş, üniversite öğrencisi).

Sinir oluyorum Trabzonlu olup da Trabzonspor'u tutmayanlara sinir oluyorum. Ya böyle bir insan değilim ama bu konuda böyleyiz, nasıl oluyor ben de anlamıyorum. Bu bebeklikten içimize işleniyor. Hani mesela siyaset olsun, din olsun ya abi bırakın kim neyi tutarsa tutsun. Hele böyle iki insan çatıştığı zaman sinir oluyorum. Özgürlük, düşünce hakkı var, lütfen bunları aşın artık ama söz konusu Trabzonlu olup da başka takımı tutmak olunca, ya yok Trabzonspor'u tutmak zorundasın illaki. Bilmiyorum mesela arkadaşlarım ateistmiş, Müslümanmış, Hristiyanmış hiç umurumda olmaz. Ama bu söz konusu olunca herkes Trabzonsporlu olmak zorundaymış gibi diye bir alg1 var (K2, kadın, 21 yaş, üniversite öğrencisi).

Trabzonluların Trabzonspor'u tutması gerektiğini düşünen katılımcılar, aynı zamanda Trabzon'un biraz da Trabzonspor sayesinde var olduğunu düşünmektedir. Söz konusu çıkarım, Trabzonspor'un kenti temsil ettiği düşüncesiyle de örtüşmektedir. Ankette yer alan "Trabzon, Trabzonspor sayesinde var olmuştur" ifadesine cevap verenlerin \%26,8'i “kesinlikle katılıyorum”, \%16,1'i “katılıyorum” (toplamda \%42,9), \%22,2'si "ne katılıyorum ne katılmıyorum", \%15,6's1 "katılmiyorum” ve \%19,4'ü "kesinlikle katılmıyorum” (toplamda \%34,9’u katılmıyor) demiştir.

Tablo 3

"Trabzon, Trabzonspor sayesinde var olmuștur"

\begin{tabular}{|l|c|c|}
\hline Kategori & Sayı (Kişi) & Geçerli \% \\
\hline Kesinlikle katılmıorum & 76 & $19,4 \%$ \\
\hline Katılmıorum & 61 & $15,6 \%$ \\
\hline Ne katıliyorum ne katılmıorum & 87 & $22,2 \%$ \\
\hline Katılıyorum & $\mathbf{6 3}$ & $\mathbf{1 6 , 1 \%}$ \\
\hline Kesinlikle katılıyorum & $\mathbf{1 0 5}$ & $\mathbf{2 6 , 8 \%}$ \\
\hline Toplam & 392 & $100,0 \%$ \\
\hline
\end{tabular}

Bu sonuçlara göre, Trabzonspor kentle özdeşleşmiş bir spor kulübüdür. Hatta kentin gündelik hayatı futbol maçlarına göre düzenlenmektedir. Trabzonspor maçı öncesi çoğu dükkân erkenden kapanmakta, öğrenciler sınava hazırlanmayı ertelemektedir. Yıllardır şampiyonluk görmeyen kent sakinleri kazandıkları herhangi bir maçta kenti bayram yerine, kaybettiklerindeyse matem yerine çevirmektedirler. Kısacası kentin nabzını belirleyen Trabzonspor'dur. Öyleyse Trabzonspor ve futbol gençlerin gündelik hayatlarında oldukça önemli bir yere sahiptir. Özellikle Trabzonspor'a dair inşa edilen toplumsal hafizanın gençlerin kente olan aidiyeti üzerinde oldukça etkili olduğu görülmektedir. Söz konusu hafıza şampiyonluk ve travma yıllarına ilişkindir.

Trabzonspor 1974-1975 sezonunda Türkiye 1. Futbol Ligi’ne yükselmiştir. 1975-1976 sezonunda ise, Trabzonspor lig şampiyonu olmuştur. Böylece ilk defa bir Anadolu takımı 
kupayı almış ve futbolda İstanbul takımlarının hâkimiyeti kırılmıştır. Bu şampiyonlukla ve ardından gelen diğer şampiyonluklarla (art arda alınan Cumhurbaşkanlığı Kupaları, Başbakanlık Kupaları, Lig Şampiyonlukları gibi) ${ }^{6}$ birlikte Trabzonspor Anadolu’yu temsil eden bir takım haline gelmiş, Anadolu'nun çeşitli yerlerinden Trabzonlu olmasalar da Trabzonspor'a destek veren taraftar kitlesi oluşmuştur (Tunç, 2011: 193-199; Talimciler, 2017: 489; Eroğlu, 2010: 345). Günümüzde 1983-1984 sezonundaki Trabzonspor şampiyonluğundan beridir hiç şampiyonluk görmeyen, ancak şampiyonluk anlatılarıyla büyüyen Trabzonspor taraftarları büyük bir çoğunluğu oluşturmaktadır (Eroğlu, 2010: 338). Bu anlatılar da ortak bir hafızanın oluşmasını ve böylece zamansal ve mekânsal mesafelerine rağmen taraftarlar arasında bir köprü kurulmasını sağlamaktadır. Bu anlatılar sayesinde Trabzonspor taraftarlarının toplumsal hafizası aktarılabilmektedir. Geçmiş bugünde bir anlatı şeklinde yeniden inşa edilerek hatırlanmaktadır (Halbwachs, 1997: 119).

Örneğin, mahallelerden çıkan futbolcuların para için değil kent için Trabzonspor'da mücadele ettiğini söyleyen derinlemesine mülakat katılımcıları o dönemin futbolunu efsaneleştirmekte Trabzonspor'a kutsiyet atfetmektedir.

Ya evde maç izliyor, bakıyorsun benim babamı kızdıracak, sinirlendirecek, bu denli reaksiyonları kolay vermeyen adam onu izlediği zaman veriyor. Yani birisini yani bir kadına veya bir erkeğe âşık olurcasına reaksiyonlar gösteriyor. Diyorsun ki demek kutsal bir şey, önemli bir şey değer yani. Bu çok farklı, bu kolay böyle lanet dayım bir şey değil. Çocuk aklınla beraber onu şey yapıyor. Kutsal yani mesela o kadar. Yani dolayısıyla Trabzonsporluyuz. Biz önce Trabzonsporlu olduk. Ondan sonra Trabzonsporlu olmanın gururlanma sebebi, verilerini sonra öğrendik. Ben Trabzonsporlu olduğumda Trabzonspor'un altı kere şampiyon olduğunu bilmiyordum. İstanbul takımlarının saltanatlarını bozduğunu da bilmiyordum. Güçlülere karşı güçsüz mahalle çocukları olarak o başarı hikâyelerini elde ettiklerini de bilmiyordum. Avrupa'da Liverpool gibi işte büyük takımları o mütevazı kadrosuyla yendiğini de bilmiyordum. Şampiyon olduktan sonra efsane kadrodaki iki ismi pastaneye gidip çay içtiklerinde ceplerinde çay parası bile olmadığını da bilmiyordum. $\mathrm{O}$ insanların kahveden çıkıp maça gittiklerini de bilmiyordum. Tamamıyla bir amatör ruhları olduğunu da bilmiyordum. Bir sürü şey. Ha ondan sonra evet bağlanma noktasında böyle düşündüğün zaman, evet yani o İstanbul saltanatını yıkması, güçlülere karsı güçsüzlerin, merkeze karsı taşranın, zengine karsı fakirin, aristokrata karsı köylünün, adını ne koyarsan koy birçok dikatomi böyle çerçevesinde hep zayıf tarafta olanın güçlüleri yendiği, onlara karsı onlara rağmen başarı kazandığı durumdan dolayı bir gurur duymak durumu var. Ama ben bu takımı bu yüzden mi tuttum? Belki de bu yüzden bırakamıyorum, ama bu yüzden tuttum desem yalan olur. Çünkü Trabzonspor'u tuttum, ben anlamadım ki yani ne ara tuttum ne yaptım (K1, erkek, 26 yaş, doktora öğrencisi).

6 Trabzonspor'un birinci lige çıktığg 1974 yılından 1983-1984 sezonundaki son şampiyonluğuna ve günümüze kadar olan süreçte 6 lig şampiyonluğu, 5 lig ikinciliği, 7 Cumhurbaşkanlığı Kupası, 5 Başbakanlık Kupası, 6 Türkiye Kupası bulunmaktadır. Trabzonspor ayrıca Avrupa kupalarında Liverpool, Barcelona, Inter Milan gibi takımlarla oynamış ve bu takımlara karşı maçlar kazanmıştır. Bkz.: Ö. K. Öymen (2016). Trabzon ve Futbol. İçinde: H. Kulaçoğlu (der), Fırtına, İhtilâl, Efsane: Trabzonspor, 5. Bask1, İstanbul: İletişim Yayınları, 15-24, 17. Sunay Akın ise hiç bilinmeyen bir şampiyonluğu daha ekler. 1987 yılında İmralı Yarı Açık Cezaevi'nde futbol turnuvası düzenlenmiştir ve tutuklular oluşturdukları takımların forma ihtiyaçları için spor kulüplerinden destek almak üzere onlara mektup göndermişlerdir. Siyasi tutuklulardan oluşan takım Trabzonspor'a mektup yazar ve Kulüp forma, şort, spor ayakkabı ve top gibi ihtiyaçlarnı gönderir. Formaların rengi bordo-mavidir. Diğer mahkûmlar ise mektuplarına yanıt alamamışlardır. Cezaevi'nde gerçekleştirilen turnuvayı ise bu bordo mavi formaları giyen takım kazanır. Bkz.: S. Akın (2016). Trabzonspor'un Bilinmeyen Şampiyonluğu. İçinde: H. Kulaçoğlu (der), Fırtına, İhtilâl, Efsane: Trabzonspor, 5. Baskı, İstanbul: İletişim Yayınları, 328-332, 332. 
O yılları görmemiş olmalarına rağmen Trabzonspor taraftarı olan bütün gençler, bu ortak hafızayı çok net bir şekilde hatırlamaktadır. Zamansal olarak birlikte olunmasa da topluluğun diğer (geçmiş ya da gelecekteki) üyeleri, hafızalarda varlıklarını hissettirmektedir. Anıların hatırlanması için şampiyonluk yıllarını yaşayanların anlatılarının aktarılması yeterlidir (Halbwachs, 1997: 98). Söz konusu hafıza da onların Trabzonspor'a olan bağlılığını artırmaktadır, çünkü efsaneleşmiş bu anlatılar sayesinde Trabzonspor bir gurur kaynağı haline dönüşebilmektedir. Bu aynı zamanda bir mekân anlatısıdır, çünkü hikâyeleşmiş her anlatı bir mekânda geçmektedir. Bu anlatının mekânı ise hem Hüseyin Avni Aker Stadyumu hem de Trabzon'dur. Söz konusu anlatı mekân bilincinin oluşmasını sağlamakta, bir yeri insanileştirmekte, mekânsallaştırmakta ve mekânsal varoluşu gerçekleştirmektedir (Schick, 2000: 25). Benzer şekilde anlatı da mekân sayesinde somutlaşmakta, gerçek anlamına kavuşmaktadır. Yeri mekâna çeviren mekân anlatıları efsaneye dönüştükçe gücünü artırmaktadır. Hatırlanan sadece şampiyonluk yılları değildir. Şampiyonlukların kıl payı kaçırıldığı ve taraftarında travma etkisi yaratan efsaneleşmiş başka anlatılar da bulunmaktadır.

Trabzonspor, 1974-1985 yılları arasındaki gibi bir başarıyı uzun yıllar elde edememiştir. $\mathrm{Bu}$ nedenle 1995-1996 ve 2010-2011 sezonlarında şampiyonluğa yaklaşmak, ancak elde edememek tüm Trabzonlu ve Trabzonsporlular için büyük travmalara neden olmuştur. Söz konusu travmalar derinlemesine mülakat katılımcıları tarafından sıkça dile getirilmiştir. 1995-1996 sezonunda Fenerbahçe ve Trabzonspor şampiyonluk yarışına girmişlerdir. Bu sezon sonunda Trabzonspor liderliğini korumaktadır ve Fenerbahçe'yi yenmesi durumunda şampiyon olacaktır. Maç Trabzonspor'un üstünlüğü ile sürerken, Fenerbahçe'nin 2-1'lik galibiyeti ile sonuçlanmıştır. Böylece Fenerbahçe Trabzonspor'un iki puan önüne geçmiş ve Trabzonspor şampiyonluğu kıl payı kaçırmıştır. Bu yenilginin ardından iki genç intihar etmiştir (Eroğlu, 2016: 493-502).

Kentin yarısının kanser olma sebebidir. Kendi evinde Fenerbahçe'yi yenememek, şampiyonluğu kaybetmek. Ağabeylerimiz vardı burada. Serkan abi der ki hani Allah kimseyi o 95-96 sezonundaki Fener maçındaki sessizliği yaşatmasın (K17, erkek, 19 yaş, üniversite öğrencisi).

Mesela şu 96 yılında facia dediğimiz 2-1'lik Fenerbahçe mağlûbiyeti bizim Trabzon halkının baya canını sıkmış. Yani şampiyonluğa oynadığımız bir maçta Fenerbahçe ile kafa kafaya gittiğimiz, hatta önde olduğumuz bir maçta puan olarak, biz Fenerbahçe'yi ağırlıyoruz. Maçta 1-0 öne geçiyoruz ondan sonra, o zamanki teknik direktörümüz Şenol Güneş sanırsam bazı hatalı hareketler yapıyor. Hatalı değişiklikler mi diyeyim, hatalı taktikler mi diyeyim. Mesela bizim eski futbolcularımızdan Ünal Karaman o zaman takımın en iyisiymiş onu dışarı almış. Yani 1-0 önde iken biz neredeyse o zaman şampiyonluk mu ne garanti oluyormuş neredeyse garantileyecektik neredeyse, yani teknik direktörümüz o maçta hücum oynatmış galiba saldırmışız galiba. Ondan sonra maç 1-0'dan 2-1 oldu. Kendini asan bir taraftar olmuş diyebilirim, galiba benim yaşlarımda bir taraftar kendini asmış (K6, erkek, 19 yaş, üniversite öğrencisi).

Yukarıdaki anlatılarda katılımcılar yaşamadıkları bir dönemin acı olaylarından bahsetmektedir. Söz konusu travmaların hatırlanması ortak bir duygunun yaratılmasında önemli bir role sahiptir. Taraftarların birbirlerine kenetlenmelerini sağlamaktadır. Çünkü toplulukta acı hissi uyandıran bu türden hatıralar ortak ama derin bir iz birakmaktadır (Candau, 1998: 147-151). Katılımcıların ortak anlamlar yükledikleri söz konusu olaylar onların bir hayali cemaat oluşturmalarını sağlamaktadır. Birbirlerini yakından tanımayan 
Trabzonspor taraftarları aynı olayları anlatmakta, zihinlerinde birbirlerinden habersiz bir şekilde canlı tutmakta ve ortak bir duygu yaratmaktadır. Tıpkı ulusun hayal edilmiş bir siyasal topluluk olması gibi, futbol takımı taraftarlarından oluşan bir 'cemaat' de hayal edilmiştir. Bu cemaati oluşturan hiçbir birey birbirlerini yakından tanımamakta, temas etmemekte ancak birbirlerinin varlığını hayal etmektedir (Anderson, 2004: 20-21).

Tek kâbus 1995-1996 sezonunda kaybedilen şampiyonluk değildir. Günümüz gençlerinin deneyimine denk gelen şampiyonluğa yaklaşılan ama elde edilemeyen 20102011 sezonu da katılımcıların sıkça dile getirdiği travmalardan biridir. Bu travmanın ardından bilinçli bir şekilde hayatına son verenler olmamıştır, ancak söz konusu olay gençlerin futbola ve adalete olan inançlarını yitirmelerine sebebiyet vermiştir. Gençler artık futbola da güvenmemektedir.

Ya mesela ben 6 yasındayken işte 96'da o Fener kâbusu oldu bütün Trabzon 10 sene geri gitti. Ya kâbus diye nitelendiriyorum ki o bizim babalarımızın döneminin kâbusuydu. Bizim kâbusumuz da 2011 oldu. Her kuşağa bir tane denk geldi yani. Ve acı bir şey, ben 2011 'den sonra zaten futbola biraz daha mesafeli olmamın ilgimi kaybetmemin en önemli sebeplerinden, gerekçelerinden bir tanesi 2011'de yaşanan o şike skandalı (K1, erkek, 26 yaş, doktora öğrencisi).

2011 sezonu bence Trabzonlulara göre ve gerçekten adalet çerçevesinde değerlendirdiğimiz zaman şampiyon bizdik, biz olmalıydık (K19, kadın, 22 yaş, üniversite öğrencisi).

Zaten kupamızı da yediler, şampiyonluğumuzu da yediler. Biz her zaman saygılı durduk. Hiçbir zaman ödün vermedik. Hiçbir zaman çirkefleşmedik. Çirkefleşenleri görüyoruz zaten. Bizim her zaman dik, saygılı bir duruşumuz var. Yani hiçbir zaman bunu bozmadık, bozmayacağız da (K16, kadın, 21 yaş, kuaför çırağı)

Şike tartışması Trabzonspor taraftarlarında hatırlamak istemedikleri ama unutamadıkları önemli bir travma yaratmıştır. Derinlemesine mülakat katılımcılarının hemen hemen hepsi Trabzonsporludur (2'si takım tutmamaktadır), ancak 2010-2011 sezonundan sonra futbola karşı soğuduklarını belirtmişlerdir. Katılımcılar 2011 şampiyonunun Trabzonspor olduğuna inanmaktadır; hatta kendi nesillerinin tek gördüğü şampiyonluk olarak kabul etmektedir. Şampiyonluk ve travma yıllarına dair kurgulana gelen anlatıların yanında futbol maçlarının oynandığı ve izlendiği mekânlar da gençlerin toplumsal hafizasında önemli bir yere sahiptir ve onların belleklerinde yer eden bu mekânlar kentle özdeşleşmelerini sağlamaktadır.

Trabzon'un futbol tarihine bakıldı ğında geçmişte futbol maçlarının Kavak Meydanı ${ }^{7}$ nda yapıldığı bilinmektedir. Bu mekân tarihsel süreç içerisinde yer değiştirmiştir. Mekânların yer değiştirmesi Kavak Meydanı'ndan Hüseyin Avni Aker'e (ilk adı Cumhuriyet Stadyumu) ve oradan da Akyazı'daki Medical Park Şenol Güneş Spor Kompleksi'ne şeklinde olması mevcut ekonomik ve toplumsal dönüşümün bir sonucudur. Hüseyin Avni

7 Kavak Meydanı çeşitli bayram törenleri için de kullanılan bir mekândı. Futbol maçlarının rağbet görmesi üzerine kentin ileri gelenlerinin desteği ile buraya bir stadyum yapılmasına karar verilmiştir. 1927 yılında inşa edilmeye başlanan ve adı Cumhuriyet Stadı olarak belirlenen kent stadyumunun yapımı hiçbir zaman tamamlanamamıştır. Farklı farklı dönemlerde yapımının tamamlanması girişimleri olmuştur. İnşaatı 1951'de tamamlanan Stadyumun ismi 1970'lerde Selim Sırrı Tercan'ın İstanbul'daki beden eğitimi kursunda eğitim almış, Trabzon'un ilk beden eğitimi ögretmenlerinden ve Trabzon futboluna katkı sunmuş olan Hüseyin Avni Aker'in ismi verilerek değiştirilmiş̧tir. Antrenmanlar ise yine kentin futbol hafizasında yer eden bir mekân olan Kavak Meydanı'nda yapılmaya devam etmiştir. Kavak Meydanı'ndan Şehir Stadyumu'na geçiş aynı zamanda amatörlükten profesyonelliğe geçişin simgesel işaretleridir. Bkz.: S. Tunç (2011). Trabzon'da Futbolun Toplumsal Tarihi: Mektepliler, Münevverler, Meraklılar. İstanbul: İletişim Yayınları, 46-49, 118-120. 
Aker Stadyumu, anıların birikeceği kadar uzun bir zamandan beri var olmasından ötürü canlı ve konuşan bir mekândır. Medical Park Şenol Güneş Spor Kompleksi ise, ekonomik ve siyasi iktidarın kendi heybetini gösterebildiği yerlerden biridir.

K8 (kadın, 20 yaş, satış danışmanı) Hüseyin Avni Aker’i “insanın doğduğu ev gibi bir yer" olarak tanımlamaktadır. Kavak Meydanı nasıl ki Trabzon futbolunun hafizasında yer eden bir mekânsa, Hüseyin Avni Aker Stadyumu da benzer şekilde Trabzonspor taraftarının kolektif hafıza mekânı olarak yer almaktadır. Hafıza mekânı toplumsal hafızanın işler olduğu, yani hatırlamanın aktif bir şekilde gerçekleşmesinin sağlandığı bir yer, bölge, şehir veya mahalle olabilmektedir (Candau, 1998: 153). Deneyimlenen mekân, toplumsal hafizanın sahiplerinden izler taşımakta ve bu izler o mekânda karşılaşılan, buluşulan kişilerin hatırlanmasını sağlamaktadır. Dolayısıyla mekânın zihindeki tahayyülü toplumsal hafızanın oluşmasında bir role sahiptir. O mekâna ait her bir detay ise kolektif bir anlam içermektedir (Halbwachs, 1997: 194-196). Hüseyin Avni Aker Stadyumu'nu çok özleyeceğini dile getiren K9 (erkek, 19 yaş, berber çırağı), K19 (kadın, 22 yaş, üniversite öğrencisi), K16 (kadın, 21 yaş, kuaför çırağı) ve K10 (erkek, 19 yaş, berber çırağı) duygularını aşağıdaki gibi aktarmaktadır:

Yani iyi bence ama Avni Aker'i yıkmasalar iyi olur aslında. Çoğu kişinin mesela mazisi, anısı var orda. Babalarımız anlatıyor, diyor ki "biz 30 bin kişilik statta 40-50-60 bin kişi maç izlerdik." Baya kalabalık girer, maç izlerdik diyor. İşte o zaman herkes herkesi tanırdı, maça giderdik, izlerdik falan filan. Oranın ayrı bir mazisi, ayrı bir anısı var. Trabzonspor maçına gitmeyen kimse yoktur Trabzon'da. Tabii güzel stad yapıldı, güzel bir yer yani, şart tabii yapılması. "Herkese yapıldı, bize niye yapılmadı?" derdi sonuçta Trabzonspor halkı, insanı yani. İyi oldu aslında ama tabii yıkılacaksa yıkılacak bir şey de diyemiyorsun (...) Avni Aker benim için bir anlam, benim için Trabzonspor'u simgeliyor. Trabzon'u simgeliyor daha doğrusu. Trabzon'u simgeleyen bir tek yer ama yani benim için değil de daha çok büyüklerim için, dedelerim için çok şey simgeliyor. Kapanışına falan gittim o kapanışta bile tüylerim diken diken oldu, oturup ağlıyordum nerdeyse yani. Sonuçta Trabzon'u simgeleyen bir yer, Trabzonspor'un tarihi olan bir yer, yani şampiyonlukları yaşadığı bir yer. İlklerin olduğu bir yer. Az sonra kapanacak bura yani. Yeni bir yer kurulacak, bir şey diyemiyorsun, olacak oluyor yani (K9).

Ya benim hoşuma gitti Akyazı'ya taşınması, çünkü Trabzon artık büyük bir şehir oldu ve böyle her şeyin merkezde yığılması hoş bir şey değil. Hani işte büyük hastane burada olsun, Avni Aker burada olsun, ne gerek var ki. Trabzon geniş büyük bir yer, kullanalım diğer yerleri de. Oraya taşınması da benim hoşuma gitti. Daha da güzel oldu (...) Ama Avni Aker'in yıkılmasını ben istemem, çünkü yani çok fazla maneviyat taşıyor. Şampiyon orda olunmuş, o yüzden yıkılmasından ziyade orda kalsın bir şekilde, o ruh mesela. 1461 takımımız da var bizim altyapıda. Hani o mesela onu orda yansitabilirler, 1461 'in ruhunu. Avni Aker bence kapanmasın hiç bir şekilde. Hatta onun adı bile bana böyle daha şey geliyor, belki alışkanlıktan hoşuma gidiyor (K19).

Yıkılması tabii ki üzer. Anı sonuçta hani. Trabzon'un hani bir Ayasofya müzesi varsa oranın da bir Avni Aker Stadyumu var. Orayı da öyle benimsemiştik. Her geçişimizde "bak işte bu Trabzon'un stadı." Nasıl İstanbul'dan geçerken Fenerin stadyumu falan var, biz de burada Avni Aker'i gösteriyorduk. Ama şimdi daha güzel bir yeri gösteriyoruz. Kocaman Şenol Güneş Stadyumu. Avni Aker'in yıkılmasını istemem, farklı amatör takımların devam etmesini isterim (K16).

Avni Aker abla benim için ruh yatıyor. Paha biçilemez mekânların, anıların olduğu yer. Orayı yıkmak yani nasıl diyeyim duygularını yok etmek gibi geliyor bana (K10, erkek, 19 yaş, berber çırağı). 
Hüseyin Avni Aker Stadyumu bir tarihi imlemektedir. Geçmişteki hatıraların cisimleştiği bir anıt, hafıza mekânıdır. Hatıralar ancak mekânsallaştıkları zaman güçlü kalabilmektedir (Bachelard, 2013: 39). Hafıza mekânları zamanı durdurmakta, unutmayı engellemekte, ölümü ölümsüzleştirmekte ve soyut olanı somutlaştırmaktadır. Bu mekânlar hem maddi hem işlevsel hem de semboliktir. Bir gruba özgü işaretlerle donanmıştır ve bir içeriğe, anlama, somut bir bedene ve tarihe sahiptir (Nora, 1997: 3438). Bu stadyum kente hâkim olan futbolun tarihini, şampiyonluk yıllarını, aynı zamanda travmaları hatırlatmakta ve ortak duygunun canlı kalmasını sağlamaktadır.

Yeni stad kesinlikle yabancılaşacağım bir mekân olacak. Hani daha gitmeden konuşuyoruz ama önyargılı olacağım bir yer olacak. Hüseyin Avni Aker'in şuan mevcut bulunduğu yerin yanında Yavuz Sultan Selim sahası diye bir tane mabet de var. Oranın tarihi dokusu var. Asıl futbolcular oradan çıkmış. 19 Mayıs Kapalı Spor Salonu var, Trabzon lisesi var, o mahalle var. Anlatabildim mi? Ama Akyazı bir AVM gibi, yalnızca araçla gidebileceğin bir yer. Yürüyüp de gidebileceğin bir yer değil. Biz maçların çoğuna Meydan'dan yürüyerek giderdik. O iki kilometrelik yolu yürüyerek hani giderdik. Ve bu hani daha böyle bir maçtan önce bir motivasyon kaynağıydı. Şimdi dolmuştan ineceksin, maça gideceksin, son derece lüks koltuklar işte. Avni Aker'de 1slanıyorduk iliklerimize kadar, hasta oluyorduk. Dolayısıyla ben yeni stadın aynı tadı vereceğini hani düşünmüyorum. Yeni stadın yapılmasına da karşıdım. Denizin doldurulmasına zaten karşıydım. Şuan eski stadın yerini en azından tribünlerinin yıkılıp, o yeşil saha sınırlarının korunup, kalelerinin ve korner bayraklarının çizgilerin dahi korunup, oranın bir açık hava müzesi seklinde olmasını çok isterim. Ama muhtemelen böyle olmayacaktır (K1, erkek, 26 yaş, doktora öğrencisi).

Katılımcılar da şimdiden bir özlem duymaktadır Hüseyin Avni Aker’e karşı. $\mathrm{Bu}$ nedenle ya alt yapıdaki takımlar için bir stad olarak kullanılması ya da müzeye dönüştürülmesi gerektiğini düşünmektedir. Artık geçmişin izlerinin takip edilebildiği eski bir kentsel yapı haline gelen Hüseyin Avni Aker Stadyumu anlatı üreten bir aktördür ve Trabzon'a ruh katmaktadır (de Certeau ve Giard, 2015: 166). Hüseyin Avni Aker Stadyumu'nun yıkılması fikri ise derinlemesine mülakat katılımcıları için tarihe karşı bir ayıptır. Mekânda gerçekleştirilen geçmiş deneyimler, yani ortak hatıralar (etkileşimci geçmiş) eski mekâna olan bağlılığı artırmaktadır. Aynı işlevde kullanılmak üzere geçilen yeni mekân ise, benzer duygunun oluşmasını sağlayamamaktadır (Milligan, 1998: 1214). Hatıralarda canlılığını koruyan Hüseyin Avni Aker Stadyumu geçmiş ile bugün arasında bir köprü oluşturmakta ve toplumsal hafiza etrafında aidiyetlerin oluşmasına katk1 sunmaktadır (Bilgin, 2013: 137).

Trabzonspor taraftarları ile birlikte, aynı renk kıyafetlerle ve aynı şarkıları söyleyerek, sloganlar atarak stadyuma doğru yürümek hem geçilen sokakları, toplanılan yerleri, stadyumu bir mekâna dönüştürmekte hem de kişiler arasında birlik, beraberlik ve “aynılık” duygusunun pekişmesini sağlamaktadır. Derinlemesine mülakat katılımcıları için Trabzonspor tek renk altında toplanarak tek bir vücut olabilmek demektir. Onlara göre, Trabzonspor tüm farklılıkları bir arada tutabilen, Trabzonluların bir bütün olabilmesini sağlayabilen bir çatıdır. Stadyum ise cinsiyet, sınıf, siyasi görüş gibi tüm farklıkların silindiği homojen bir bütünlüğün hissedildiği bir yerdir. Stadyumda kadınlar "bacı", sağcılar ve solcular "kardeş" olmaktadır. 


\section{Sonuç}

Ortak anlamlar çerçevesinde insanileştirilen ve bir aidiyet mekânına dönüştürülen Trabzon onu deneyimleyen gençler ve diğer Trabzonlular tarafından sürekli yeniden inşa edilmektedir. Bu anlamda, mekânı ve mekâna özgü oluşan farklı gençlik deneyimlerini anlamak için, onu kullananların gündelik hayat pratiklerine, birlikte ürettikleri ortak anlamlara, sembollere ve bireysel hikâyelerine bakmak gerekmektedir. $\mathrm{Bu}$ çalışmada anket, derinlemesine mülakat ve doküman inceleme gibi hem nicel hem de nitel araştırma teknikleri uygulanarak gençlerin hayat hikâyeleri ile gündelik hayat pratiklerine ilişkin bilgiler edinilmeye çalışılmıştır. Trabzon'da yaşayan ve kendilerini Trabzonlu hisseden gençlerin hikâyelerinde ve anlatılarında oldukça önemli bir yere sahip olan Trabzon, onlar için bir kimlik yerine dönüşmektedir. Bu şekilde kent, tarihselliği ve toplumsallığ içinde canlı bir varlığa dönüşebilmekte, bir ruha sahip olabilmektedir. Bu ruhu yaratan ise, orada yaşayan gençlerin (ve diğer Trabzonluların) hatıraları, deneyimleri, duyguları ve ona yükledikleri anlamlardır. Bu şekilde Trabzon gençler için herhangi bir yer olmaktan çıkmakta, insanileşmekte, kelimenin tam anlamıyla mekânsallaşmaktadır.

Mekânın bu inşası gençlerin kente olan aidiyetini de pekiştirmektedir. Söz konusu aidiyet kentin kültürel, coğrafi, toplumsal, ekonomik ve siyasal özellikleri ile ilişkili olarak inşa edilmektedir. Ancak çalışma kapsamında daha çok kente dair mitselleştirilmiş anlatılar ve Trabzonspor taraftarlığı üzerinde durulmuştur. Kentle bütünleşmiş bir spor dalı olan futbol ve Trabzonspor, Trabzon'u deneyimleyen gençlerin mekâna olan aidiyetlerini kuvvetlendirmekte, gündelik hayatlarını ona göre organize etmelerini sağlamaktadır. $\mathrm{Bu}$ şekilde, onu farklı şekilde deneyimleyen, algılayan ve anlamlandıran gençler kendilerini güvende ve rahat hissettikleri Trabzon'u insanileştirmekte, mekânsallaştırmakta ve bir yuvaya dönüştürmektedir. Benzerleriyle girdikleri etkileşim ve biriktirdikleri geçmişe (çocukluklarına) dair hatıralar onların bu mekâna kök salmalarını sağlamaktadır. Yoğun bir içeridelik hissi ile 'bura' olarak imledikleri Trabzon, gençler için hem övünülecek bir yer hem de bir kader olmaktadır. Bu anlamıyla aşkla bağlanılan ve kendilenen bu kente duyulan his 'yer sevgisine' dönüşmektedir. Gençlerin kent aidiyetinin oluşmasını sağlayan bir diğer önemli husus ise, kentin bölgenin ve ülkenin en güvenli yeri olduğuna dair üretilen mitsel anlatılardır. Gençler hem bu anlatıların yeniden üretimine katılmakta hem de onlar üzerinden aidiyetlerini inşa etmektedir.

Trabzon'da yaşayan gençlerin kente dair efsaneleşmiş anlatıların yeniden üretimine katıldıkları ve bu anlatılar aracılığıyla mekânsallaştırdıkları Trabzon ile özdeşleşebildikleri görülmektedir. Mitler aracılığıyla hayali ve kurgusal bir kent imajı yaratılmaktadır. Trabzon üzerine oluşturulan mitlerde kentin güvenli bir yer olduğu söylenmektedir. Kentin güvenli olması, kentte yaşayan erkeklerin kahramanlıkları üzerinden üretilen anlatılarda ortaya çıkmaktadır. Anlatıya göre İstanbul'un fethi Trabzon'un fethi ile tamamlanmıştır ve Trabzon Türkiye'nin kalbi ve son kalesidir. Trabzon'un düşmanlar tarafından işgali (ya da günümüzde terörist grupların saldırısına uğrayabilmesi) Türkiye'nin de artık parçalanmaya başlayacağı anlamına gelmektedir. Gençlerin de yeniden üretimine katıldıkları bu anlatı, çoğu Trabzonlu tarafindan duyulabilecek bir anlatıdır. Bu anlatı onların hem kent hem de ülke milliyetçiliği yaptıklarını göstermektedir. Bu durum aynı zamanda kentin bölgenin de merkezi olduğu inancını pekiştirmektedir. Trabzon tarihsel süreç içerisinde Karadeniz Bölgesi’nin ekonomik, toplumsal ve siyasal merkezi olma konumunu yitirmiştir, ancak 
bölgenin merkezi olduğu inancı anlatılarla kenti deneyimleyenler tarafindan sürekli yeniden inşa edilmektedir. Bu çaba tıpkı hegemonik erkekliğin içerisine girdiği iktidar krizine benzemektedir. Trabzonluların bölge üzerindeki iktidarını tamamen kaybetme korkusu, onların son bir gayretle imajın korunması ve bölgenin 'abisi' olma konumunun yeniden kazanılması için hayali bir anlatı oluşturmalarına neden olmaktadır. Bu anlatının devam edebilmesini sağlayan en önemli unsurlardan biri de Trabzonspor'dur.

Gençlerin şehir milliyetçiliğini ve kente olan aidiyetini pekiştiren öğelerden biri Trabzonspor taraftarlığıdır. Futbol, tarihsel süreçte Trabzon kenti için her zaman önemli bir spor dalı olmuştur. Günümüzde ise Anadolu'nun temsilinde önemli bir yeri olduğuna inanılan Trabzonspor'un kentin gündelik hayatını şekillendirdiği görülmektedir. Hem Kulübün renklerine bezenen hem de maç öncesi ve sonralarına göre ruhu değişen kentte gençler yetişkinliği birer Trabzonspor taraftarı olarak öğrenmektedir. Futbol, yerel düzeyde kimlik inşasında etkili olabilmektedir, çünkü taraftarlarına bir gruba ait olma imkânı tanımaktadır. Bir gruba aidiyet ise, o grubun bulunduğu mekânla olan bağını kuvvetlendirmektedir. Trabzon'da yaşayan gençlerin büyük bir çoğunluğu Trabzonsporludur ve Kulüp gündelik hayatlarının önemli bir bölümünü kaplamaktadır. Gündelik hayatlarının rengi bordo-maviden ibaret olan gençler, Trabzonspor etrafinda ortak bir duygu ve hafıza inşa etmektedir. Söz konusu hafıza, Kulübün şampiyonluk ve şampiyonlukların kaçırıldığı travma yıllarına dair kurgulanan anlatılar ile Hüseyin Avni Aker gibi geçmişle bağ kurulmasını sağlayan hafıza mekânları aracılığıyla belirginleşmektedir. Bu toplumsal hafıza da gençlerin kentle olan bağını pekiştirmektedir.

Finansal Destek: Yazar bu çalışma için finansal destek almamıştır.

\section{Kaynakça/References}

Akın, S. (2016). Trabzonspor’un Bilinmeyen Şampiyonluğu. İçinde: H. Kulaçoğlu (der), Fırtına, İhtilâl, Efsane: Trabzonspor, 5. Baskı, İstanbul: İletişim Yayınları, 328-332.

Anderson, B. (2004). Hayali cemaatler: Milliyetçiliğin kökenleri ve yayılması. Çev. İ. Savaşır, İstanbul: Metis Yayınlar1.

Assman, J. (2001). Kültürel bellek: Eski yazılı kültürlerde yazı, hatırlama ve politik kimlik. İstanbul: Ayrıntı Yayınları.

Aşk-1 Trabzon 2. https://www.youtube.com/watch?v=eBdgUyx4dRQ. Son erişim tarihi, 10.01.2018.

Bachelard, G. (2013). Mekânın poetikası. Çev. A. Tümertekin, İstanbul: İthaki Yayınları.

Bilgin, N. (2013). Tarih ve kolektif bellek. İstanbul: Bağlam Yayınları.

Bozok, M. (2013). Construction Local Masculinities: A Case Study From Trabzon, Turkey. (Basılmamış Doktora Tezi). Ankara: Orta Doğu Teknik Üniversitesi.

Bozok, M. (2016). Yoksullaşma, Sağcılık, Trabzonspor Taraftarlığı ve Nataşaların Gölgesinde Trabzon Erkekliği. İçinde: U. Biryol (der.), “Karardı Karadeniz”, 3. Baskı, İstanbul: İletişim Yayınları, 413-444.

Candau, J. (1998). Mémoire et Identité. Paris: Presse Universitaire de France.

Christou, A. (2006). Narratives of place, culture and identity: Second-generation Greek-Americans return 'Home'. Amsterdam: Amsterdam University Press.

Connerton, P. (1999). Toplumlar nasıl hatırlar. Çev. A. Şenel, İstanbul: Ayrıntı Yayınları.

Coulon, A. (2002). L'éthnométhodologie. 5. Bask1, Paris: PUF.

Coulon, A. (2015). Etnometodoloji. Çev. Ü. Tatlıcan, 2. Baskı, İstanbul: Küre Yayınları.

Cresswell, T. (2008). Place: A short introduction. Oxford/MA: Blackwell Publishing.

De Certeau, M. (2008). Gündelik hayatın keşfi I: Eylem, uygulama, üretim sanatları. Çev. L. Arslan Özcan, Ankara: Dost Kitabevi.

De Certeau, M. ve Giard, L. (2015). I. Kısım: İki Arada. İçinde: M. de Certeau vd. (der), Gündelik Hayatın Keşfi II: Konut, Mutfak İşleri, Çev. Ç. Eroğlu ve E. Ataçay, 2. Bask1, Ankara: Dost Kitabevi, 163-179.

Deniz, A. Ç. (2014). "Öğrenci İşi”’: Üniversite öğrencilerinin gündelik hayatı: İstanbul örneği. İstanbul: İletişim Yayınlar1. 
Doğan, İ. (1994). Bir alt kültür olarak ankara yüksel caddesi gençlik. Ankara: Ankara Kültür Bakanlığı Yayını. Dovey, K. (1985). Home and Homelessness. İçinde: I. Altman ve C. M. Werner (der), Home Environments. Human Behavior and Environment: Advances in Theory and Research, Say1 8, New York: Plenum Press, 33-64.

Duncan, J. S. (1985). The House as Symbol of Social Structure: Notes on the Langueage of Objects among Collectivistic Groups. İçinde: I. Altman ve C. M. Werner (der), Home Environments. Human Behavior and Environment: Advances in Theory and Research, Say1 8, New York: Plenum Press, 133-151.

Eroğlu, A. (2010). Trabzonspor tarihi üzerine bir deneme. İçinde: G. Bakırezer ve Y. Demirer (der), Trabzon'u Anlamak, 2. Baskı, İstanbul: İletişim Yayınları, 337-360.

Eroğlu, A. (2016). Kazansaydık O Maçı: 5 Mayıs 1996 Tarihinde Oynanan Trabzonspor-Fenerbahçe Maçına İlişkin Notlar. İçinde: U. Biryol (der), “Karardı Karadeniz”, 3. Baskı, İstanbul: İletişim Yayınları, 487-507.

Garfinkel, H. (2014). Etnometodolojide araştırmalar. Çev. Ü. Tatlıcan, Ankara: Heretik Yayınları.

Giraud, C. (2010). Les techniques d'enquête en sociologie. İçinde: F. de Singly vd. (der), Nouveau manuel de sociologie, Paris: Armand Colin, 38-51.

Gökaçtı, M. A. (2008). "Bizim İçin Oyna” Türkiye’de futbol ve siyaset. İstanbul: İletişim Yayınları.

Göregenli, M. (2010). Çevre psikolojisi: İnsan-mekân ilişkileri. İstanbul: İstanbul Bilgi Üniversitesi Yayınları.

Halbwachs, M. (1997). La mémoire collective. Paris: Albin Michael.

Harvey, D. (2012). Postmodernliğin durumu. Çev. S. Savran, İstanbul: Metis Yayınları.

Heidegger, M. (2004). Varlık ve zaman. Çev. A. Yardımlı, İstanbul: İdea Yayınları.

Hummon, D. M. (1992). Community Attachment: Local Sentiment and Sense of Place. İçinde: I. Altman ve S. M. Low (der), Place Attachment, New York: Plenum Press, 253-278.

Hür, A. (2010). Trabzon’un Etnik Tarihine Bir Bakış. İçinde: G. Bakırezer ve Y. Demirer (der), Trabzon'u Anlamak, 2. Baskı, İstanbul: İletişim Yayınları, 127-174.

Lefebvre, H. (2014). Mekânın üretimi. Çev. I. Ergüden, 4. Baskı, İstanbul: Sel Yayınları.

Massey, D. (1995). Places and Their Pasts. History Workshop Journal, 39, 182-192.

Massey, D. (2001). Space, place, and gender. 3. Bask1, Minneapolis: University of Minnesota Press.

Milligan, M. J. (1998). Interactional past and potential: The social construction of place attachment. Symbolic Interaction, 21(1), 1-33.

Nora, P. (1997). Entre mémoire et histoire: la problématique des lieux. Paris: Gallimard.

Öymen, Ö. K. (2016). Trabzon ve futbol. İçinde: H. Kulaçoğlu (der), Fırtına, İhtilâl, Efsane: Trabzonspor, 5. Baskı, İstanbul: İletişim Yayınları, 15-24.

Paasi, A. (2003). Region and place: Regional identity in question. Progress in Human Geography, 27(4), 475485.

Pickles, J. (1985). Phenomenology, Science and Geography: Spatiality and the Human Sciences. Cambridge: Cambridge University Press.

Proshansky, H. M. (1978). The city and self-1dentity. Environment and Behavior, 10, 147-169.

Relph, E. C. (1976). Place and placelessness. London: Pion Limited.

Schick, İ. C. (2000). Batının cinsel kıyısı: Başkalıkçı söylemde cinsellik ve mekânsallık. Çev. S. Kılıç ve G. Sarı, İstanbul: Tarih Vakfı Yurt Yayınları.

Seamon, D. (1979). A Geography of the Lifeworld: Movement, rest and encounter. London: Croom Helm.

Sevinç, B. (2014). Trabzonluluk kimliği: Bir şehrin ruhu. Trabzon: Serander Yayınları.

Shields, R. (1988). Images of Spaces and Places: A Comparative Study. (Basılmamış Doktora Tezi). University of Sussex.

Soja, E. W. (1989). Soja, Edward W. (1989), Postmodern geographies: The reassertion of space in critical social theory. London/New York: Verso.

Talimciler, A. (2017). Toplumsal Yap1 ve Değişim Ekseninde Türkiye'de Spor/Futbol: 1920-2012. İçinde: F. Alpkaya ve B. Duru (der), 1920’den Günümüze Türkiye'de Toplumsal Yapı ve Değişim, 4. Bask1, Ankara: Phoenix Yayınlar1, 479-508.

Tekeli, İ. (2013). Tarih bilinci ve gençlik. 2. Baskı, İstanbul: Tarih Vakfı Yurt Yayınları.

Tuan, Y. F. (2001). Space and place: The perspective of experience. 8. Bask1, Minneapolis/London: University of Minnesota Press.

Tunç, S. (2011). Trabzon’da futbolun toplumsal tarihi: Mektepliler, münevverler, meraklılar. İstanbul: İletişim Yayınlar1.

TÜİK (Türkiye İstatistik Kurumu) (2016). İl, Yaş grubu ve Cinsiyete Göre Nüfus 2007-2016. www.tuik.gov.tr/ PreIstatistikTablo.do?istab_id=945. Son erişim tarihi, 20.03.2017.

URL, www.61 saat.com. Son erişim tarihi, 10.03.2018.

Werner, C. M., Altman, I. ve Oxley, D. (1985). Temporal Aspects of Home: A Transactional Perspective. İçinde: I. Altman ve C. M. Werner (der), Home Environments. Human Behavior and Environment: Advances in Theory and Research, Say1 8, New York: Plenum Press, 1-32.

Yonucu, D. (2005). From the Place of the 'Dangerous Classes' to the Place of Danger: Emergence of New Youth Subjectivities in Zeytinburnu. (Basılmamış Yüksek Lisans Tezi). İstanbul: Boğaziçi Üniversitesi.

Yücel, H. (2006). Une identité générationnelle-territorial? Les jeunes d'origine alévie du quartier Gazi d'Istanbul. (Basılmamış Doktora Tezi). Paris: EHESS. 


\section{Derinlemesine Mülakat Katılımcıları}

\begin{tabular}{|l|l|}
\hline $\mathrm{K}^{8} 1:$ Erkek, 26 yaş, doktora öğrencisi & K2: Kadın, 21 yaş, üniversite öğrencisi \\
\hline K3: Kadın, 20 yaş, üniversite öğrencisi & K4: Kadın, 20 yaş, üniversite öğrencisi \\
\hline K5: Erkek, 24 yaş, A101 çalışanı & K6: Erkek, 19 yaş, üniversite öğrencisi \\
\hline K7: Erkek, 22 yaş, üniversite öğrencisi & K8: Kadın, 20 yaş, satış danışmanı \\
\hline K9: Erkek, 19 yaş, berber çırağı & K10: Erkek, 19 yaş, berber çırağı \\
\hline K11: Erkek, 22 yaş, üniversite öğrencisi & K12: Kadın, 16,5 yaş, lise öğrencisi \\
\hline K13: Erkek, 21 yaş, üniversite öğrencisi & K14: Erkek, 19 yaş, üniversite öğrencisi \\
\hline K15: Erkek, 22 yaş, üniversite öğrencisi & K16: Kadın, 21 yaş, kuaför çırağ1 \\
\hline K17: Erkek, 19 yaş, üniversite öğrencisi & K18: Kadın, 21 yaş, üniversite öğrencisi \\
\hline K19: Kadın, 22 yaş, üniversite öğrencisi & \\
\hline
\end{tabular}


